\title{
Formation of De Geer Moraines Deposited Subglacially, Central Québec
}

\author{
Formation des moraines de De Geer mises en place en position \\ sous-glaciaire, au centre du Québec \\ Bildung subglazial abgelagerter De Geer-Moränen im Zentrum \\ von Québec
}

\author{
Luc M. Beaudry et Gilbert Prichonnet
}

Volume 49, numéro 3, 1995

URI : https://id.erudit.org/iderudit/033059ar

DOI : https://doi.org/10.7202/033059ar

\section{Aller au sommaire du numéro}

\section{Éditeur(s)}

Les Presses de l'Université de Montréal

ISSN

0705-7199 (imprimé)

1492-143X (numérique)

Découvrir la revue

Citer cet article

Beaudry, L. M. \& Prichonnet, G. (1995). Formation of De Geer Moraines Deposited Subglacially, Central Québec. Géographie physique et Quaternaire, 49(3), 337-361. https://doi.org/10.7202/033059ar

\section{Résumé de l'article}

L'étude propose un modèle de formation des moraines de De Geer des régions de Chapais et de Radisson, au Québec. Il est basé principalement sur la distribution des faciès et l'analyse des structures de déformation. Trois associations de faciès ont été identifiées : (1) des sédiments triés forment des lits obliques inclinés vers l'aval de l'écoulement glaciaire, avec des lentilles de till ou de diamicton interdigitées dans les sédiments triés ou drapant le versant proximal des moraines; (2) un till non fissile et peu compact recouvre en les déformant des sédiments triés. Ce till contient parfois des laminations de sédiments fins triés; (3) un till fissile et compact repose le plus souvent sur la nappe de till de fond sous-jacente. Les trois associations de faciès présentent des structures de déformation (failles, plis, structures d'entraînement et figures de charge) indiquant une contrainte de l'amont glaciaire. Les moraines de De Geer se sont mises en place dans des crevasses situées à la base d'un glacier actif. Dans les secteurs où s'écoulaient des eaux de fonte, des sédiments triés s'accumulaient en lits obliques. Latéralement à ces secteurs, les eaux de fonte modifiaient peu les sédiments et du till s'est accumulé. Le glacier a remobilisé le till de fond, provoquant son déplacement vers des crevasses localisées en aval, ou déformé des lentilles de till. Enfin, dans les secteurs où les eaux de fonte avaient peu ou pas d'influence, les moraines se sont formées par placage de till dans les crevasses. Les trois associations de faciès font partie d'un continuum qui commence avec les séries de moraines composées de sédiment triés, passant latéralement à des moraines composées d'un till fissile et compact. Ce passage latéral est identifié pour la première fois. 


\section{FORMATION OF DE GEER MORAINES DEPOSITED SUBGLACIALLY, CENTRAL QUÉBEC}

Luc M. BEAUDRY* and Gilbert PRICHONNET, Département des sciences de la Terre, GÉOTERAP, Université du Québec à Montréal, C.P. 8888, succursale Centre-ville, Montréal, Québec H3C 3P8.

ABSTRACT This paper presents a model for the genesis of De Geer moraines in the Chapais and Radisson areas, Québec. The model is mainly based on facies and deformation structure analysis. Three facies associations have been identified: (1) sorted sediments that form foreset laminations dipping downglacier. Till lenses or glacial diamictons are found within the sorted sediments or form a surficial layer on the proximal side of the sections; (2) a nonfissile and poorly compacted till overlies and deforms sorted sediments. Laminae of finely sorted sediments may be incorporated in the till; (3) a fissile and compact till commonly lies on the basal till sheet. All three facies associations feature deformation structures (faults, folds, load and drag structures) which indicate an upglacier origin. The model proposed is an emplacement of De Geer moraines in bottom crevasses by an active glacier. In areas where meltwaters were channelized, sediments accumulated in the crevasses as foreset laminations. Till filled the crevasses in areas remote from meltwater flow. Glacial activity remobilized the basal till locally and pushed it toward bottom crevasses located downglacier, or overturned large layers of till. Finally, in areas located even further laterally, meltwaters had almost no effect and the moraines were formed by plastering of till in the crevasses. The three facies associations are part of a continuum beginning with the moraines composed of sorted sediments and grading laterally into the moraines formed of fissile and compact till. This continuum is described for the first time.
RÉSUMÉ Formation des moraines de De Geer mises en place en position sousglaciaire, au centre du Québec. L'étude propose un modèle de formation des moraines de De Geer des régions de Chapais et de Radisson, au Québec. II est basé principalement sur la distribution des faciès et l'analyse des structures de déformation. Trois associations de faciès ont été identifiées: (1) des sédiments triés forment des lits obliques inclinés vers l'aval de l'écoulement glaciaire, avec des lentilles de till ou de diamicton interdigitées dans les sédiments triés ou drapant le versant proximal des moraines; (2) un till non fissile et peu compact recouvre en les déformant des sédiments triés. Ce till contient parfois des laminations de sédiments fins triés; (3) un till fissile et compact repose le plus souvent sur la nappe de till de fond sous-jacente. Les trois associations de faciès présentent des structures de déformation (failles, plis, structures d'entraînement et figures de charge) indiquant une contrainte de l'amont glaciaire. Les moraines de De Geer se sont mises en place dans des crevasses situées à la base d'un glacier actif. Dans les secteurs où s'écoulaient des eaux de fonte, des sédiments triés s'accumulaient en lits obliques. Latéralement à ces secteurs, les eaux de fonte modifiaient peu les sédiments et du till s'est accumulé. Le glacier a remobilisé le till de fond, provoquant son déplacement vers des crevasses localisées en aval, ou déformé des lentilles de till. Enfin, dans les secteurs où les eaux de fonte avaient peu ou pas d'influence, les moraines se sont formées par placage de till dans les crevasses. Les trois associations de faciès font partie d'un continuum qui commence avec les séries de moraines composées de sédiment triés, passant latéralement à des moraines composées d'un till fissile et compact. Ce passage latéral est identifié pour la première fois.
ZUSAMMENFASSUNG Bildung subglazial abgelagerter De Geer-Moränen im Zentrum von Québec. Diese Studie stellt ein Modell der Entstehung der De GeerMoränen vor. Das Modell stützt sich hauptsächlich auf die Fazies-Verteilung und die Analyse der Deformationsstruktur. Man hat drei Fazies-Verbindungen identifiziert: (1) sortierte, steil geschichtete Sedimente, die gletscherabwärts ausger-ichtet sind. Man findet Till-Linsen oder glaziale Diamiktite entweder innerhalb der sortierten Sedimente oder als Oberflächen-schicht auf der Proximalseite der Ab-schnitte; (2) ein nicht spaltbares und wenig kompaktes Till überlagert und verformt die sortierten Sedimente; (3) ein spaltbares und kompaktes Till bedeckt weiterhin die Grundtilldecke. Alle dreie FaziesVerbindungen weisen Verformungsstrukturen auf (Verwerfungen, Falten, Schuttlastund Schleppungsstrukturen), was auf eine Entstehung im oberen Teil des Gletschers schließen läßt. Das Modell geht davon aus, daß die De Geer-Moränen von einem aktiven Gletscher in Bodengletscherspalten gebildet worden sind. In Gebieten, wo die Schmelzwasser Rinnen bildeten, lagerten sich die Sedimente in den Spalten in Schrägschichtung an. Till füllte die Spalten in vom Schmelzwasserfluß entfernten Gebieten. Die glaziale Aktivität hat örtlich das Grundtill wieder mobilisiert und es in Richtung gletscherabwärts gelegener Spalten geschoben oder es hat breite Tillschichten umgewälzt. Schließlich hatten die Schmelzwasser in Gebieten, die noch weiter seitlich lagen, fast keine Wirkung und die Moränen bildeten sich durch Anhäufung von Till in den Spalten. Die drei Fazies-Verbindungen sind Teil eines Kontinuums, das mit den Moränen aus sortierten Sedimenten beginnt und allmählich lateral in die aus spaltbarem und kompaktem Till bestehenden Moränen übergeht.

\footnotetext{
Manuscrit reçu le 9 octobre 1994 ; manuscrit révisé accepté le 17 février 1995

* Present address : 1-67 de la Fondrière, Hull, Québec J8Z 3J3
} 


\section{INTRODUCTION}

De Geer moraines have been defined as a type of minor moraine with moraine ridges which are parallel to one another (Elson, 1968). This landform usually forms a series of irregularly spaced ridges. Several authors have mentioned their presence in former postglacial lakes or shallow marine basins. The ridges are narrow and elongated, straight or sinuous, and some have appendages. Their profile may be symmetrical or asymmetrical. The material in the ridges may be till and/or sorted sediments. They were first described by De Geer (1889) and have since been known by different names such as: annual moraines (Norman, 1938; Shaw, 1944; Hoppe, 1948), wash-board moraines (Mawdsley, 1936; Hoppe, 1957), cross-valley moraines (Andrews, 1963a, 1963b; Andrews and Smithson, 1966) sublacustrine moraines (Barnett, 1967; Barnett and Holdsworth, 1974) and lift-off moraines (Gipp, 1992). Hoppe (1959) first proposed the name De Geer moraines for this type of landform.

Series of De Geer moraines cover large areas of North America (Fig. 1). In the United States, these landforms are found in Alaska and Maine. In Canada, De Geer moraines have been identified in most of the country as well as on the Scotian Shelf. These moraines, however, have been mostly studied in Québec, where they form four major belts covering areas varying from $5,000 \mathrm{~km}^{2}$ to $43,000 \mathrm{~km}^{2}$. These belts are located southeast and east of James Bay and Hudson Bay (Fig. 1). A small number of De Geer moraines also occur in a few valleys on lle d'Anticosti (Painchaud et al., 1984), and south of Lac Saint-Jean (Tremblay, 1968).

This paper describes De Geer moraines from the Chapais and Radisson areas (Fig. 1) that are respectively part of the Opémisca and Fort George Belts (Shaw, 1944). The objective is to develop a model for the origin of these moraines. The model presented here extends the one proposed by Beaudry and Prichonnet (1991), which concerned moraines composed of sorted sediments. In the present paper, the model includes all the identified facies, but only the development and emplacement of those De Geer moraines composed of till is illustrated.

The conceptual approach used here is different from that of most of the previous studies, which have been mainly based on terrain morphology, spatial distribution and till fabric analysis. Many authors (see Zilliacus 1987b, for extensive discussion on the annual moraine problem) have concluded that De Geer moraines can be used to establish the relative chronology of deglaciation. The present study is focussed on the facies variations, the primary sedimentary structures, such as paleocurrent indicators, penecontemporaneous deformation structures and the lithological composition. The relationship between De Geer moraines and drumlins and the transition between De Geer moraines and Rogen moraines is also discussed. The traditional elements (moraine morphology, spatial distribution and till fabrics) are also used as criteria for analysis. The paper is completed with a discussion of the annual moraine problem and the position of De Geer moraines in glacial landscapes.

In this study, no further reference will be made to the Opémisca and Fort George Belts because they form an almost continuous field (Fig. 1) and the areal extension of De Geer moraines is not yet known with certainty, some of them being covered by thick glaciolacustrine deposits. Nevertheless these moraine belts are separated by the Sakami moraine and are known to be diachronic (Fig. 1). The moraines of the Chapais area, located south of the Sakami Moraine, were deposited when the NouveauQuébec Glacier was in contact with Glacial Lake Ojibway ca. 8300 years BP (Hardy, 1976). The moraines of the Radisson area, located east of the Sakami Moraine, developed ca. 8000 years BP, after the drainage of the lake, when the Nouveau-Québec Glacier was in contact with the Tyrrell Sea (Hardy, 1976, 1977, 1982; Vincent, 1977; Vincent and Hardy, 1977, 1979; Hillaire-Marcel et al., 1981; Vincent et al., 1987). A few series of De Geer moraines have also been identified in the basin of Glacial Lake Mattawaskin (Bouchard, 1980). These moraines are probably contemporaneous with the first De Geer moraine series located near Radisson to the north.

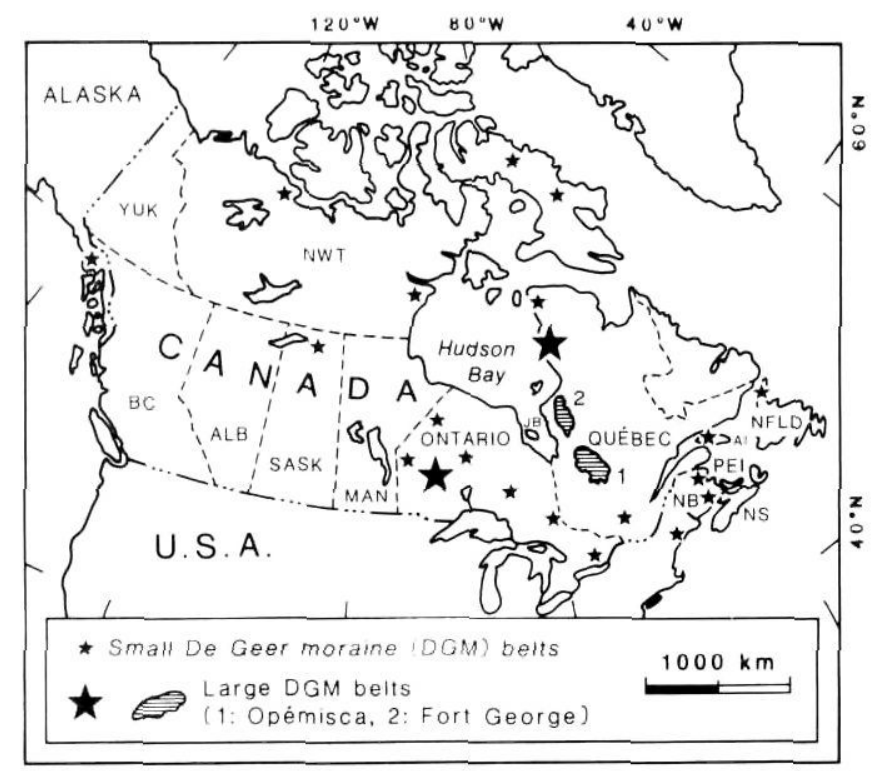

FIGURE 1. Known location of De Geer moraine belts in North America. Abbreviations: Yuk=Yukon; NWT=Northwest Territories; $\mathrm{BC}=$ British Columbia; $\mathrm{ALB}=\mathrm{Alberta} ; \mathrm{SASK}=$ Saskatchewan; MAN=Manitoba; JB=James Bay; NB=New Brunswick; NS=Nova Scotia; $\mathrm{PEI}=$ Prince Edward Island; $\mathrm{NFLD}=$ Newfoundland; $\mathrm{Al}=$ Anticosti Island; U.S.A.=United States of America; $\mathrm{SM}=$ Sakami Moraine.

Localisation des champs de moraines de De Geer en Amérique du Nord. Abréviations : YUK $=$ Yukon $; N W T=$ Territoires du NordOuest; $B C=$ Colombie Britannique ; $A L B=$ Alberta ; SASK = Saskatchewan $; M A N=$ Manitoba $; J B=$ baie de James $; N B=$ Nouveau-Brunswick $;$ NS $=$ Nouvelle-Écosse $; P E I=$ Île-du-PrinceÉdouard; NFLD = Terre-Neuve; Al= Île d'Anticosti ; U.S.A. = États-Unis d'Amérique; $S M=$ Moraine de Sakami. 


\section{GEOLOGY AND PHYSIOGRAPHY OF THE STUDIED AREAS}

The Chapais and Radisson areas are located on the Canadian Shield and are separated by a distance of $450 \mathrm{~km}$ (Fig. 2). They are underlain by Archean and Proterozoic rocks of the Superior Province (Avramtchev, 1985). The Archean lithologies include greenschist facies volcaniclastic rocks, granitic and gneissic rocks, and mafic and ultramafic rocks. The Proterozoic units are composed of slightly deformed sedimentary rocks (the Sakami and Chibougamau Formations; the Mistassini and Otish Groups). The studied moraines are located on metamorphosed volcaniclastic rocks.

The sediments from De Geer moraines have been used for road construction in both the Chapais and Radisson sectors and for the development of the La Grande Rivière

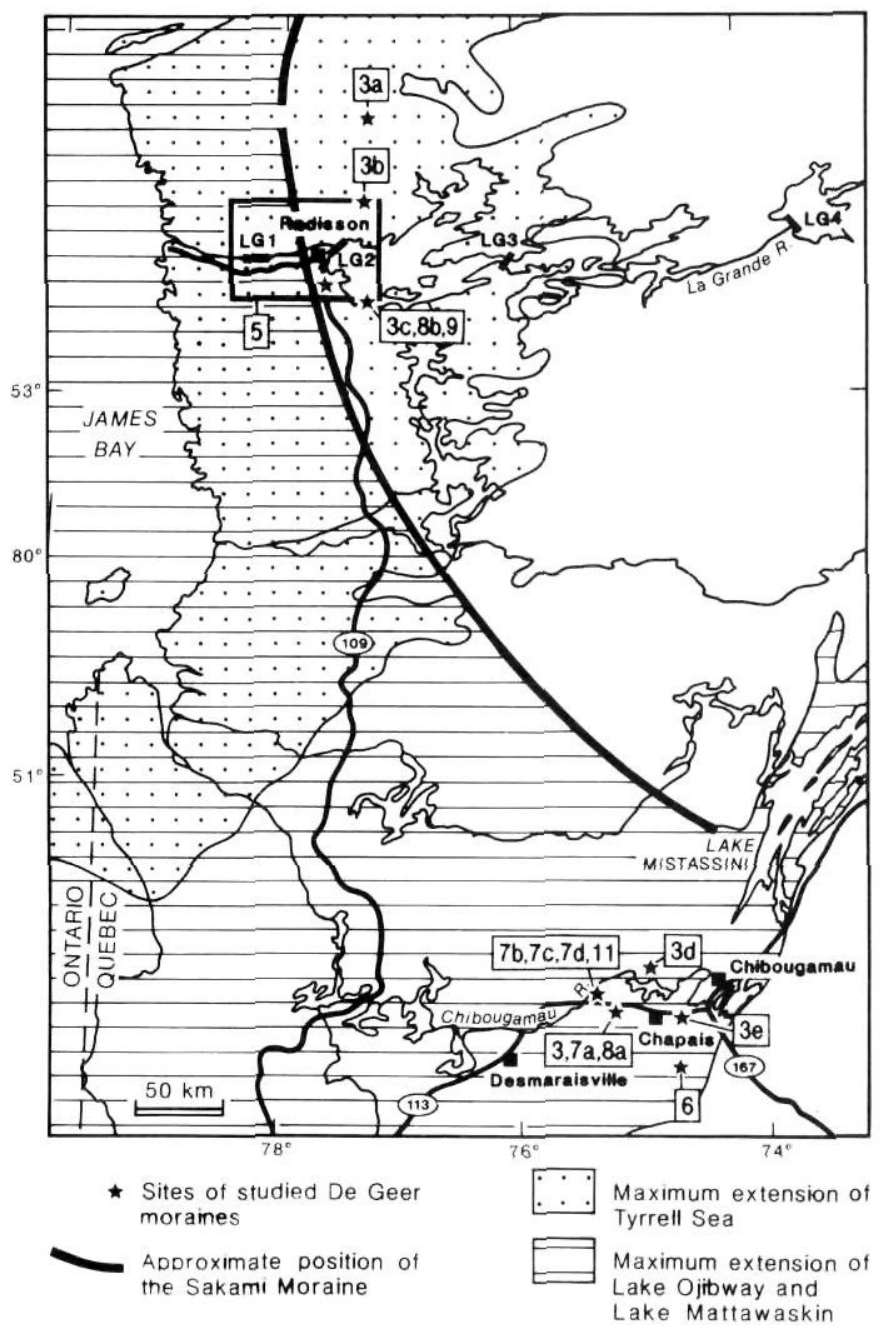

FIGURE 2. Location of the studied moraines and of the figures cited in the text (modified from Vincent 1989, fig. 3.47). LG1, LG2, LG3 and LG4 locate the dams of the La Grande Rivière hydroelectric complex.

Localisation des moraines de De Geer étudiées. LG1, LG2, LG3 et LG4 correspondent aux sites des barrages du complexe de La Grande Rivière. hydroelectric complex. Hence, those landforms are often cut by excavations, especially in the Chapais sector, where they have only recently been exploited. In the Radisson sector, a few roads have been built across the moraines, but most of the sections have been reclaimed. Ten moraines in the Chapais sector and two moraines in the Radisson sector have been excavated and described in detail (Fig. 2), from among approximately 30 observed sections.

The Chapais sector is an area of subdued relief. Elevations range from 340 to $400 \mathrm{~m}$; the maximum elevations are to the northeast of the area and the terrain slopes to the southwest. Depressions in the bedrock are partially filled by Quaternary deposits. Glacial deposits are predominant, and include till, glaciofluvial sand and gravel, and glaciolacustrine sand and clay (Prichonnet et al., 1984). Locally, bogs cover extensive areas whereas bedrock outcrops over only $2 \%$ of the studied sector (Beaudry and Prichonnet, 1991, fig.2). A maximum overburden thickness of $33 \mathrm{~m}$ was observed during a large drilling program for mineral exploration (Burns et al., 1986; Brereton et al., 1987).

The Radisson sector is part of the James Bay Lowlands. Relief is slightly undulating with elevations varying from 210 to $150 \mathrm{~m}$ near the LG2 Reservoir and slowly decreasing westward. Quaternary deposits are composed of till, glaciofluvial sediments, marine sediments (Tyrrell Sea clay, littoral and tidal flat deposits) and of fluvial and organic sediments (Vincent, 1985a, b). Bedrock outcrops form at least $50 \%$ of the ground surface.

\section{GENERAL GLACIAL CONTEXT}

The areas studied were covered by the Nouveau-Québec Glacier several times during the Quaternary Period. In the Chapais area, a sequence of three successive ice flows has been discussed by Martineau et al. (1984), Prichonnet et al. (1984), Bouchard and Martineau (1985), whereas Prichonnet and Beaudry (1990) have described a sequence of four Wisconsinan ice flows. The direction of the oldest ice flow was toward the southeast. It was probably contemporary with the northwest ice flow direction identified by Veillette and Pomares (1991) west of Desmaraisville. These divergent ice flows could be related to the Mistassini Ice Divide of Dyke and Prest (1987). The southeast ice flow was followed by a southward ice flow and then by a southwest ice flow. This southwest ice flow was responsible for the development of most of the regional till sheet and the glacial landforms. Finally, a west-southwest ice movement took place. All these ice flows were related to the displacement of the Mistassini Ice Divide from an area located northeast of Desmaraisville (Fig. 2) toward NouveauQuébec. In the Radisson area, only a west-southwest ice flow direction has been identified (Hardy, 1976; Vincent, 1977; Vincent et al., 1987; our data). In both areas, the moraines are associated with the latest stages of deglaciation, and are therefore perpendicular to the latest ice flow directions which were SW and WSW in the Chapais area and WSW in the Radisson area. 


\section{GEOMORPHOLOGY OF THE STUDIED MORAINES}

\section{MORAINES OF THE RADISSON AREA}

The moraines of the Radisson area have been called annual moraines by Shaw (1944) and De Geer moraines by Vincent (1977). They form a series of parallel segments 30 to $900 \mathrm{~m}$ apart, with an average distance of $190 \mathrm{~m}$. This spacing was measured on the surficial deposits maps of Vincent (1985a and b). Their height varies from one to ten metres, however the moraines are often partially buried under more than a metre of marine clay. Vincent (1977) has observed that the moraine widths vary from 5 to $150 \mathrm{~m}$ and their length from 50 to $1500 \mathrm{~m}$. According to Vincent (1977, p. 5 and 12), alignments of moraines many kilometres long would correspond to frontal positions of the retreating Nouveau-Québec Glacier. Another feature observed on the surficial deposit maps of Vincent (1985a, b) is that the series of moraines is discontinuous. They form patches of moraines interrupted by areas of significant bedrock exposure.

The moraines of three sectors located north and south of Radisson have been mapped in detail (Fig. 3a, b and d; for location see Fig. 2). Although their morphology may at first appear regular, most of the moraines are chevron-shaped. A few other moraines have appendages oriented at an angle or perpendicular to the main segment. These appendages seem to be contemporaneous with the emplacement of the main segment since no deformations or truncations were observed. Such a truncation of De Geer moraines by a frontal moraine emplaced during a readvance was mapped in Norway by Larsen et al. (1991). Another morphological feature illustrated in Figure $3 c$ is the upglacier curve of the moraines in steeply sloping areas. This was also noted by Vincent (1977) north of La Grande Rivière.

\section{MORAINES OF THE CHAPAIS AREA}

The Chapais area moraines have been named washboard moraines (Mawdsley, 1936), annual moraines (Norman, 1938; Shaw, 1944) and De Geer moraines (Martineau, 1984; Bisson, 1987; De Corta, 1988; Beaudry, 1988; Beaudry and Prichonnet, 1991). The moraines form a series of successive segments spaced at intervals ranging from 15 to $550 \mathrm{~m}$ with an average of $180 \mathrm{~m}$. This spacing was determined from air photographs and surficial deposit maps, and was measured perpendicular to the crest of the moraines. Their height, measured in the field, varies from 1 to $15 \mathrm{~m}$, but these landforms are often partially covered by glaciolacustrine clay (up to $3 \mathrm{~m}$ ) and/or by sand and gravel from an offlap sequence $(0.5$ to $1.5 \mathrm{~m})$, so that the crests generally emerge from the deposits by 3 to $6 \mathrm{~m}$. Their width varies from 5 to $100 \mathrm{~m}$ and their length from 20 to $1400 \mathrm{~m}$. Although some segments are perfectly aligned with others, reaching a total length of 4 to $5 \mathrm{~km}$, the spatial distribution of the moraines is often irregular. The moraines may be short and closely spaced, or of variable length and separated by larger distances between crests (Beaudry, 1988, fig. 2.5).
The external geometry of the moraines is variable (Fig. $3 \mathrm{~d}$ and e). Some segments are straight, whereas others are chevron-shaped or crescent-shaped. Most of the moraines observed in the field and on air photographs are in fact chevron-shaped and, as pointed out by Prichonnet et al. (1984, fig. 17), the moraines seem to be composed of coalescent segments which meet at a $25^{\circ}$ angle. Many moraines consist of a main segment with perpendicular or oblique appendages. Field observations (geomorphology and few cross sections) show that these appendages and the main segments contain the same facies. No evidence of truncation or deformation were found. A section was also cut at the junction of a moraine and an appendage, and no deformation was observed in the primary sedimentary structures. It is believed that they were deposited contemporaneously. Moraines forming a grid network have been identified north of Lac Opémisca (Fig. 3d). At this locality, a few main segments are joined by an appendage that is parallel to ice flow. Mawdsley (1936) also identified such a moraine network in the study area, and Strömberg (1965, fig. 6) mapped a similar network in the Vänge area, Sweden.

\section{SPATIAL RELATIONSHIP WITH OTHER GLACIAL LANDFORMS}

\section{Relationship with drumlins}

De Geer moraines cut drumlins obliquely or perpendicularly in both sectors (Figs. $3 a, b, c$ and 4; for location see Fig. 2). Figure 5 (see Fig. 2) illustrates the drumlins and De Geer moraines from a $5,200 \mathrm{~km}^{2}$ surface of the Radisson area. De Geer moraines do not occur west of the Sakami Moraine whereas drumlins are numerous. Drumlin density is 26 drumlins $/ 100 \mathrm{~km}^{2}$. By contrast, east of the Sakami Moraine, De Geer moraines are abundant and the drumlin density drops to 4 drumlins $/ 100 \mathrm{~km}^{2}$.

In the Chapais area, another situation is observed. Near the eastward limit of Glacial Lake Ojibway, $45 \mathrm{~km}$ southeast of Chapais, the drumlin density calculated from the surficial deposit map of De Corta (1984), is 36 drumlins/ $100 \mathrm{~km}^{2}$ and De Geer moraines are scarce. Thirteen kilometres east of Chapais the drumlin density, reported on the surficial deposit map of Bisson (1987), drops to 20 drumlins $/ 100 \mathrm{~km}^{2}$ whereas the De Geer moraines are more numerous. West of Chapais, the drumlin density has not been calculated, but field observations show that these landforms are much less frequent and De Geer moraine density increases. Therefore it appears that the drumlin density decreases toward the interior of the Glacial Lake Ojibway basin whereas the number of De Geer moraines increases.

Variations in the morphology of De Geer moraines where they cross drumlins have been discussed by Hardy (1976, fig. 10). In some areas, he observed that the moraines are poorly formed and lie directly over the drumlins. Elsewhere, the moraines are more prominent and the sediments that form the drumlins seem to have been reworked to the point that the drumlins have been almost totally re-shaped. 
In the areas studied, the transition between drumlins and De Geer moraines (Figs. $3 a$, b and $c$ and $4 a$ and b) is not the same as that which was observed by Hardy (1976). Near Radisson, the drumlins cut by De Geer moraines have a deformed outline (Fig. $3 a, b$ and $c$ ). The drumlins that are not cut by $\mathrm{De}$ Geer moraines keep their typical outline. In Figure 3a, a drumlin truncated just upglacier of a De Geer moraine has been observed on a large scale air photograph. The drumlin morphology clearly suggests that part of its sediments were reworked by the glacier to form a local De Geer moraine. A similar phenomenon has been observed near Chapais (Fig. 4a). Most of the moraines are located over areas where a drumlin appears to have been deformed. A few occurences of moraines lying on the uplacier extremity of drumlins have been observed (Fig. 4b). This portion of the drumlin appears to be truncated, and its material seems to have been pushed downglacier.

Prichonnet et al. (1984) observed push structures in the ablation till forming the surficial portion of a drumlin located $22 \mathrm{~km}$ east of Chapais. This till contains folded laminations of sand and silt. The identification of these structures and other stratified diamictons (Prichonnet, 1984, fig. 11) suggest that the glacier was still active at the latest stages of
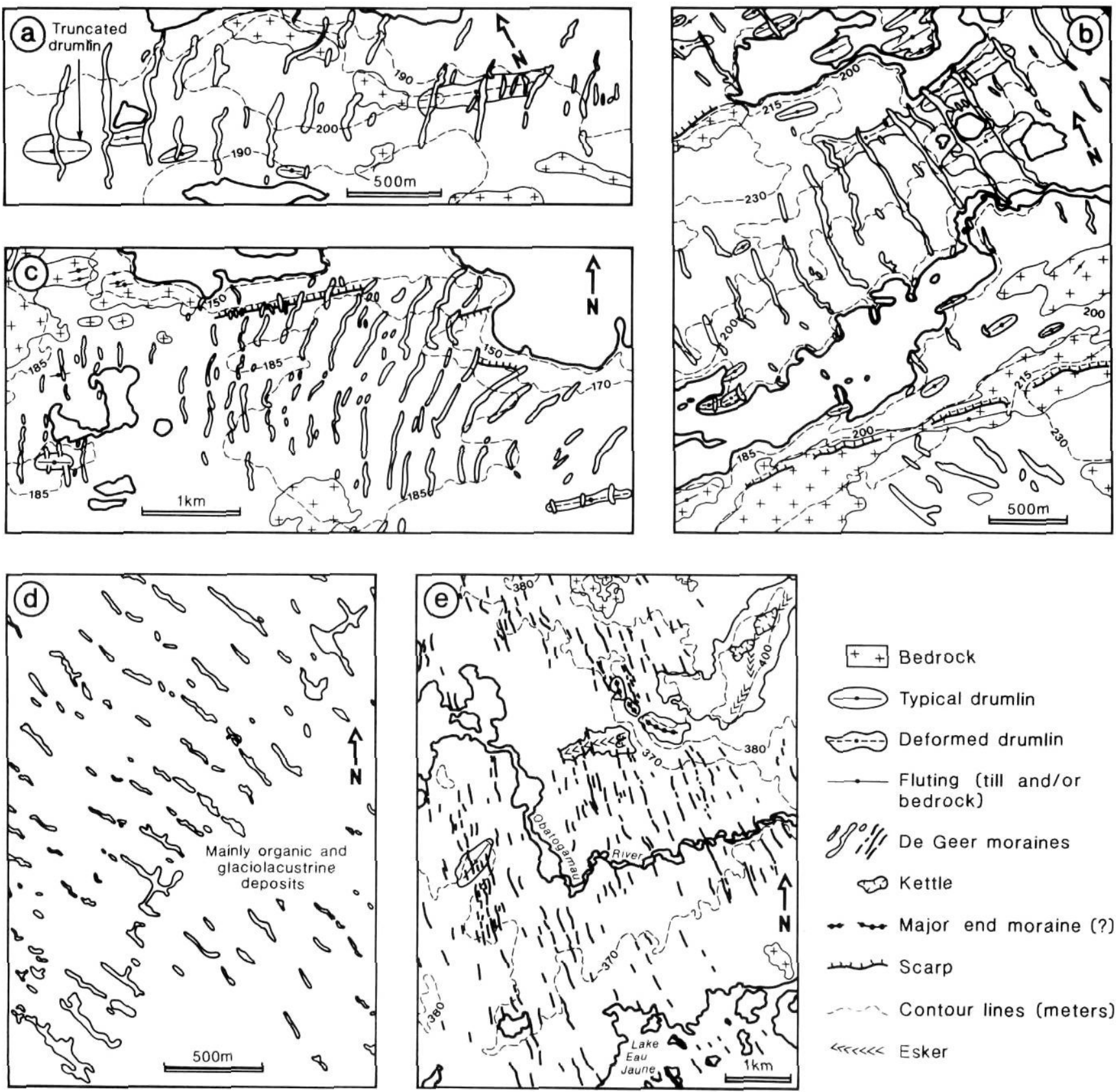

FIGURE 3. Detailed maps of De Geer moraines and other important geomorphological features of the Radisson sector $(a, b$ and $\mathrm{c}$ ) and Chapais sector ( $\mathrm{d}$ and e). For location, see Figure 2.

Cartes détaillées des moraines de De Geer et d'autres formes géomorphologiques des régions de Radisson $(a, b$ et $c)$ et de Chapais ( $d$ et $e$ ). Voir la localisation à la figure 2. 

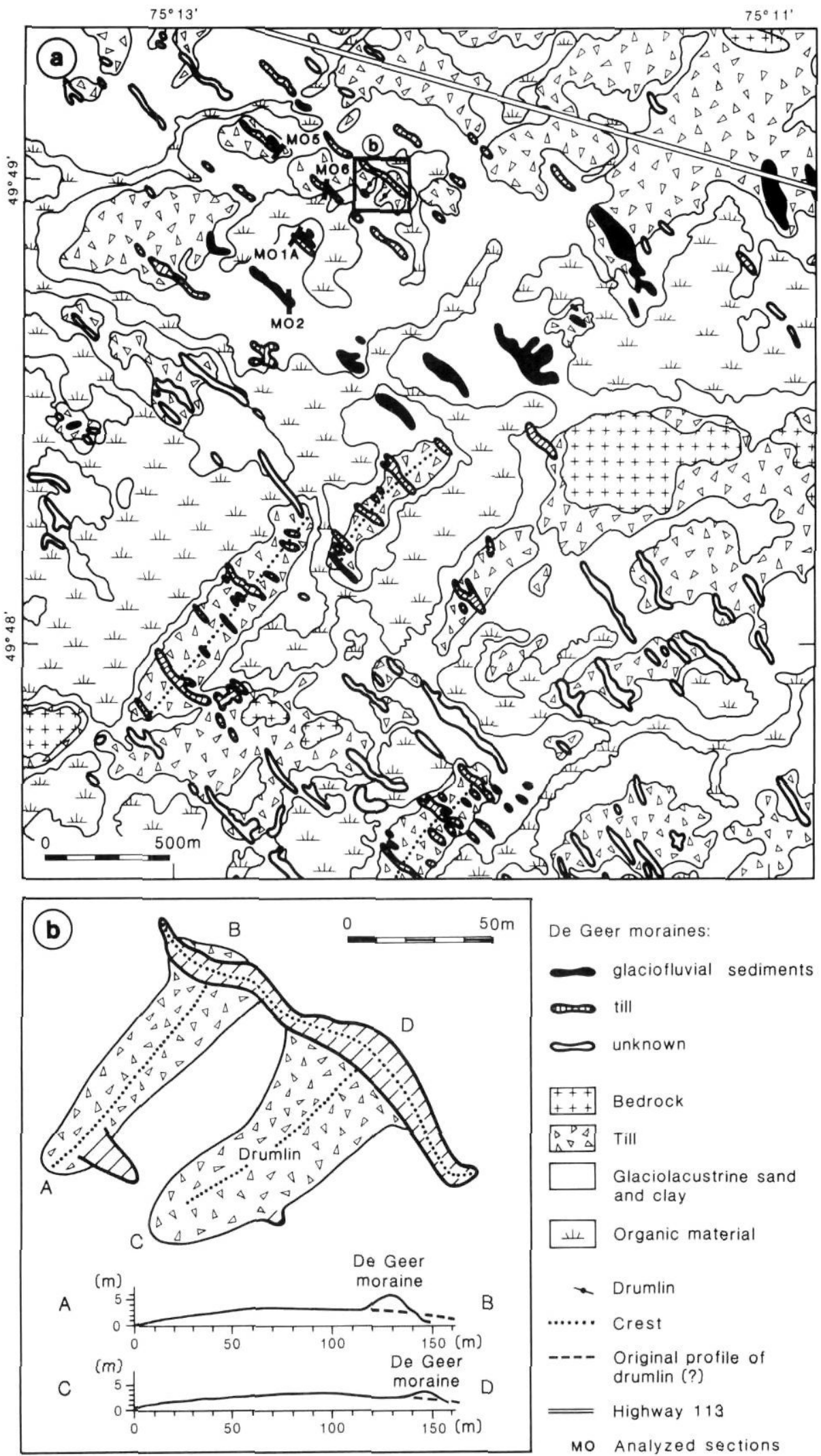

De Geer moraines:

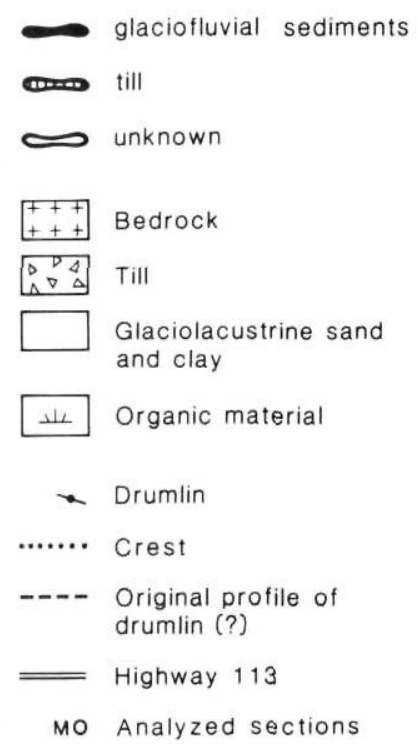

FIGURE 4. a) Surficial deposit map of a sector located $25 \mathrm{~km}$ west of Chapais. Note the series of De Geer moraines composed of sorted sediments and the relationship with deformed drumlins (modified from Beaudry and Prichonnet, 1991); b) detailed morphology of De Geer moraines crosscutting drumlins (see box in a; modified from Beaudry, 1988). For location, see Figure 2.

a) Carte des dépôts meubles d'un secteur localisé $25 \mathrm{~km}$ à l'ouest de Chapais. Noter les séries de moraines de De Geer constituées de sédiments fluvioglaciaires et la relation entre les moraines de De Geer et les drumlins déformés (modifiée de Beaudry et Prichonnet, 1991) ; b) morphologie détaillée de moraines de De Geer recoupant des drumlins (voir encadré en a ; modifiée de Beaudry, 1988). Voir la localisation à la figure 2. 


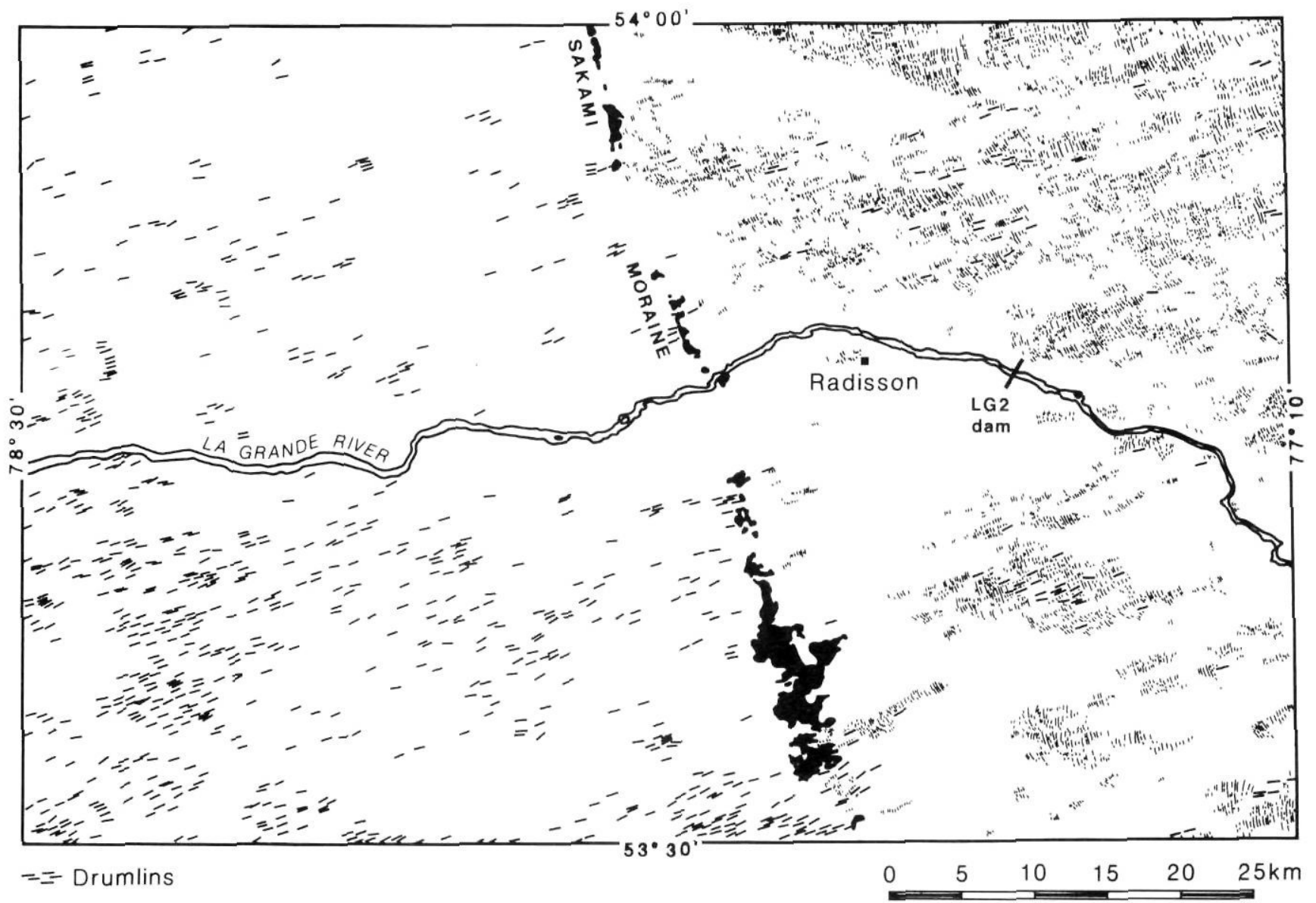

Hilin: De Geer moraınes

FIGURE 5. Map of the drumlins and De Geer moraines on both sides of the Sakami Moraine (modified from Vincent 1985a and b). West of the moraine, the drumlin density is 26 drumlins $/ 100 \mathrm{~km}^{2}$. East of the moraine, the drumlin density is 4 drumlins $/ 100 \mathrm{~km}^{2}$. For location, see Figure 2.

deglaciation, when De Geer moraines were formed. This is also emphasized by the description of many push structures (folds, thrust faults) in moraines composed of stratified sediments (Beaudry and Prichonnet, 1991, figs. 3, 4, 5, 6 and 8 ).

The observations made in both areas when combined with Hardy's (1976), Prichonnet (1984) and Prichonnet et al. (1984) data suggest that the sediments from many drumlins have been reworked by the glacier resulting in the development of a series of De Geer moraines.

\section{Relationship with eskers}

In both areas, a few eskers cross the zones where De Geer moraines are numerous. Figure $3 e$ illustrates a particular relationship between a one kilometre long esker segment, with a ENE/WSW orientation, and De Geer moraines. On the figure, De Geer moraines appear to be cutting the esker. But detailed observations showed that the outline of the esker seems to result from the coalescence of a series including at least seven De Geer moraines. The crest of the esker is sharp but its slopes undulate where the moraines cut the landform, and the moraines do
Carte des drumlins et des moraines de De Geer localisés des deux côtés de la moraine de Sakami (modifiée de Vincent 1985a et b). A l'ouest de la moraine, la densité des drumlins est de 26 drumlins $/ 100 \mathrm{~km}^{2}$. A l'est de la moraine, la densité des drumlins est de 4 drumlins $/ 100 \mathrm{~km}^{2}$. Voir la localisation à la figure 2.

not appear to have been deposited on the surface of the esker.

\section{Relationship with Rogen moraines}

Near Chapais, De Geer moraines are numerous and they exhibit the morphological characteristics described in the introduction since they form series of narrow and elongated ridges parallel to one another. Thirty kilometres east of Chapais, near the eastern limit of Glacial Lake Ojibway, De Geer moraines become more massive and they grade into Rogen moraines outside of the glacial lake basin (De Corta, 1984).

Figure 6a illustrates the glacial landforms of a $60 \mathrm{~km}^{2}$ area located $40 \mathrm{~km}$ SSE of Chapais (for location see Fig. 2). The central depression of this area is occupied by Lac Caopatina. During deglaciation, the ice flowed southwesterly. Transitional landforms between Rogen moraines and De Geer moraines have been mapped in detail. The terrain slopes toward the southwest and De Geer moraines are located on the upglacier side of the basin. These narrow, elongated moraines are oriented oblique to the ice movement which was responsible for shaping the drumlins. 

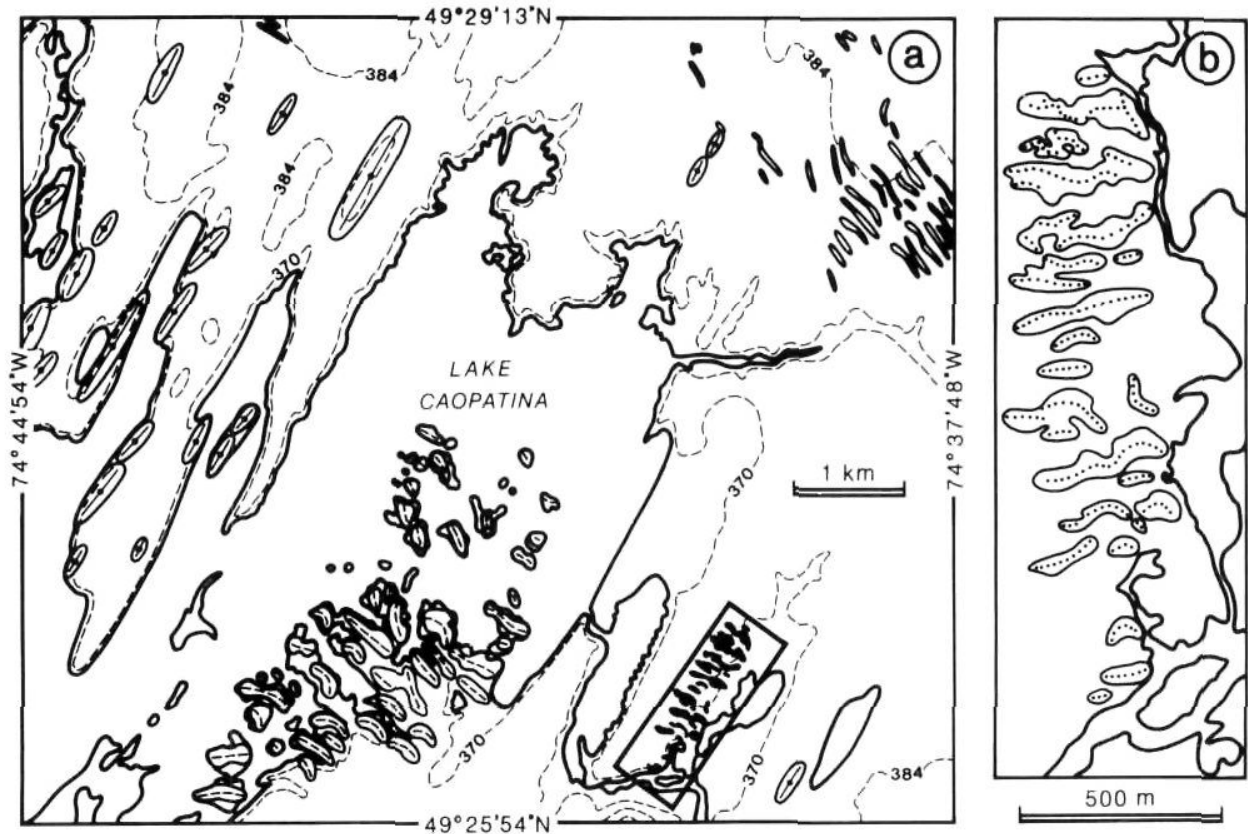

FIGURE 6. a) Map of the main geomorphological features of the area of Lac Caopatina; b) detailed morphology of the transitional moraines (see box in a). For location, see Figure 2.

a) Carte des formes géomorphologiques du secteur du lac Caopatina ; b) morphologie de détail des moraines de transition (voir encadré en a). Voir la localisation à la figure 2 .

Minor moraines

1800 De Geer type

๑ঙ્થી Rogen type hid $\%$ Transitional landforms

...... Crest of transitional landform
Rogen moraines are located on the downglacier side of the basin where the terrain slopes toward the northeast. These large, elongated moraines are oriented transverse to ice flow as deducted from the drumlins, and have horns pointing downglacier. This constitutes a characteristic feature of Rogen moraines (Lundqvist, 1989; Bouchard, 1989). In the underlined area located east of the Rogen moraines, another type of minor moraine has been mapped (Fig. 6b) which does not have the characteristic morphological features of either Rogen moraines or De Geer moraines. It is believed that this type of minor moraine has not been previously described but no name is attributed to it in order to avoid complicating the minor moraine nomenclature. The most characteristic morphological feature of these minor moraines is that they are composed of very close segments. The individual segments of the landform appear to be similar in form to De Geer moraines, since they are narrow and elongated. Each segment has a very sharp crest and the moraines can be composed of up to three segments roughly parallel to one another. Their morphology and their transitional position between Rogen moraines and De Geer moraines suggest that they could correspond to De Geer moraine segments that were pushed into clusters. The geometry of the basin could have favoured an extensive ice flow where De Geer moraines are found and a compressive flow where the Rogen moraines are located. The transitional landforms could then represent the change from an extensive flow to a compressive flow.

\section{DESCRIPTION OF THE FACIES AND INTERNAL STRUCTURES}

In the following section, several terms are used to distinguish different types of sediments. A few of them are defined here to avoid confusion. Diamicton is a descriptive word applied to a poorly sorted sediment composed of many size fractions. It may be nonsorted as in till (Dreimanis, $1982,1988)$, but it may also have been partially or almost totally winnowed of its fine particles by water. Till is a nonsorted "sediment that has been transported and deposited by or from glacier ice, with little or no sorting by water" (Dreimanis, 1988, p. 34). Till may also be described as a nonsorted sediment, compact or loose, fissile or non-fissile, occasionally containing lenses of sorted sediments, with striated clasts and boulders, that has not undergone significant sorting by water. The term till is used here in the context just defined and its use is based on detailed field and laboratory analysis. The term basal till is applied to the regional till sheet that may have been deposited by the action of active ice flow. Waterlain till corresponds to a sediment deposited directly by the glacier, but in water (Dreimanis, 1979). It has all the characteristics of a till, but its fine particles were washed out.

De Geer moraines were deposited in glaciolacustrine or marine basins. When the water retreated either because of the isostatic uplift (Tyrrell Sea) or the northern drainage of Glacial Lake Ojibway, part of the sediments were reworked by wave action. These reworked sediments were deposited on the slopes of the moraines as stratified sediments. These units are referred to as the offlap sequence which generally has a maximum thickness of about one metre and pinches out toward the moraine crest; often it begins with a thin layer of sand grading into gravelly to bouldery coarser material. In many cases, these units are entirely composed of gravel. The coarsening upward sequence was caused by increasing wave energy as the water level decreased. 
About 60 exposures were examined in the field in various degrees of detail, but only the most important moraines are discussed here. Three major facies associations have been recognized (Table I). This distinction is based on their sediments, internal structures and their spatial relationships.

\section{FACIES 1}

This facies corresponds to moraines composed of sorted sediments in proportions varying from 80 to $100 \%$. This facies has been described and interpreted by Smith (1982) and by Beaudry and Prichonnet (1991). Thus, only its most important characteristics are described herein.

The moraines presenting this facies usually form a series of up to 15 successive segments parallel to one another, but are sometimes found as isolated forms. In the Chapais area, it is estimated that this facies may represent about $15 \%$ of the De Geer moraines. In the Radisson area, no such estimate was possible because exposures are rare.

The sediments are stratified and the laminations always dip downglacier and extend parallel to the moraine axis (Fig. 7a, b, c and d; for detailed data, see Beaudry and
Prichonnet, 1991, tables 1 and 2). In some sections, parts of the laminations are cut by thrust faults and modified by overturned to recumbent folds (Figs. $7 a, b$ and d). These deformation structures are generally limited to the uppermost proximal portion of the sections but in some cases deformation structures extend over the entire exposure. Several fault planes and axial planes of folds were measured and they all dip upglacier, perpendicular to the moraine axes. The thrust faults show translocation downglacier. Some sections contain diamicton and/or till on their proximal side (Fig. 7a and b), forming lenses that were injected upwards in the stratified sediments or deposited as a surficial sheet thinning toward the central portion of the sections.

\section{Lithological composition}

Three petrographic analyses (417 to 809 clasts) were carried out on three samples of the moraines shown on Figure 7a (see also Beaudry and Prichonnet, 1991, fig. $6 \mathrm{C})$. The samples were taken in different parts of the section, one from the till lens and two from the younger diamictons. The results show that volcaniclastic debris of a local origin predominate, but their proportion diminishes (whereas the proportions of granites and gneiss increase),

TABLE I

Characteristic features of the three facies described

\begin{tabular}{|c|c|c|c|}
\hline Facies & 1 & 2 & 3 \\
\hline $\begin{array}{l}\text { Number of described } \\
\text { moraines }\end{array}$ & 4 & 6 & 2 \\
\hline \multicolumn{4}{|l|}{ Long axis orientation } \\
\hline Chapais & $115^{\circ}$ to $155^{\circ} 295^{\circ}$ to $335^{\circ}$ & $125^{\circ}$ to $130^{\circ} 305^{\circ}$ to $310^{\circ}$ & $100^{\circ}$ to $280^{\circ} 130^{\circ}$ to $310^{\circ}$ \\
\hline Radisson & Not observed & $110^{\circ}$ to $290^{\circ} 020^{\circ}$ to $200^{\circ}$ & Not observed \\
\hline \multicolumn{4}{|l|}{ Length of sections } \\
\hline Chapais & 6.4 to $31.0 \mathrm{~m}$ & 5.0 to $13.0 \mathrm{~m}$ & 5.0 to $10.0 \mathrm{~m}$ \\
\hline Radisson & Not observed & 12.0 to $16.0 \mathrm{~m}$ & Not observed \\
\hline Main features & $\begin{array}{l}\text { Sandy to sorted sediments } \\
\text { forming foreset laminations }\end{array}$ & $\begin{array}{l}\text { Poorly compacted and non fissile till } \\
\text { Till overlying and deforming stratified } \\
\text { sediments }(N=1)\end{array}$ & $\begin{array}{l}\text { Compact and fissile till } \\
\text { sometimes overlying and } \\
\text { deforming sorted sediments }\end{array}$ \\
\hline $\begin{array}{l}\text { Percentage in section } \\
\text { of sorted sediments of till }\end{array}$ & $\begin{array}{l}80 \text { to } 100 \% \\
\text { up to } 20 \%\end{array}$ & $\begin{array}{l}\text { up to } 40 \% \\
60 \text { to } 100 \%\end{array}$ & $\begin{array}{l}\text { up to } 40 \% \\
56 \text { to } 100 \%\end{array}$ \\
\hline $\begin{array}{l}\text { Primary structures } \\
\text { Paleocurrents }\end{array}$ & $\begin{array}{l}\text { Inclined laminations and } \\
\text { incorporated clasts dip toward } \\
\text { distal side of moraine }(\mathrm{N}=4)\end{array}$ & $\begin{array}{l}\text { Inclined laminations in fine stratified } \\
\text { sediments dip toward distal side of } \\
\text { moraine }(\mathrm{N}=1)\end{array}$ & Not observed \\
\hline Laminations in till & Not observed & Upglacier dip $(\mathrm{N}=2)$ & Not observed \\
\hline \multicolumn{4}{|l|}{ Deformation structures } \\
\hline Contact between facies & Upglacier dip $(\mathrm{N}=3)$ & Upglacier dip ( $\mathrm{N}=4)$ & Upglacier dip $(\mathrm{N}=1)$ \\
\hline Axial plane of folds & Upglacier dip $(\mathrm{N}=2)$ & Sub-horizontal $(\mathrm{N}=1)$ & Upglacier dip $(\mathrm{N}=1)$ \\
\hline Shear planes & Upglacier dip $(\mathrm{N}=3)$ & Upglacier dip & Not observed \\
\hline \multirow[t]{2}{*}{ Other features } & $\begin{array}{l}\text { - Till lens injected on proximal } \\
\text { side of sections }(\mathrm{N}=2)\end{array}$ & $\begin{array}{l}\text { - Fine sediments wrapped in a till } \\
\text { syncline }(N=1)\end{array}$ & - Well developped fissility \\
\hline & $\begin{array}{l}\text { - Lens of diamicton on proximal } \\
\text { side of section }(\mathrm{N}=2)\end{array}$ & $\begin{array}{l}\text { - Gradual contact between sorted } \\
\text { sediments and overlying till }\end{array}$ & $\begin{array}{l}\text { - Waterlain till between sorted } \\
\text { sediments and till }(N=1)\end{array}$ \\
\hline
\end{tabular}

$\mathrm{N}=$ number of moraines in which the features were observed and measured 


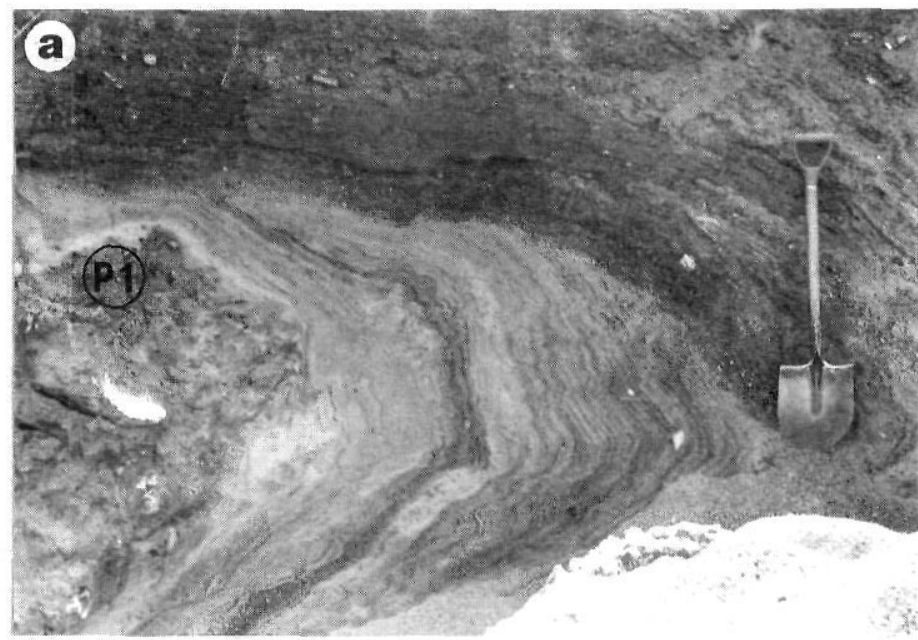

(P1)

Pebble count

\section{F Fault}
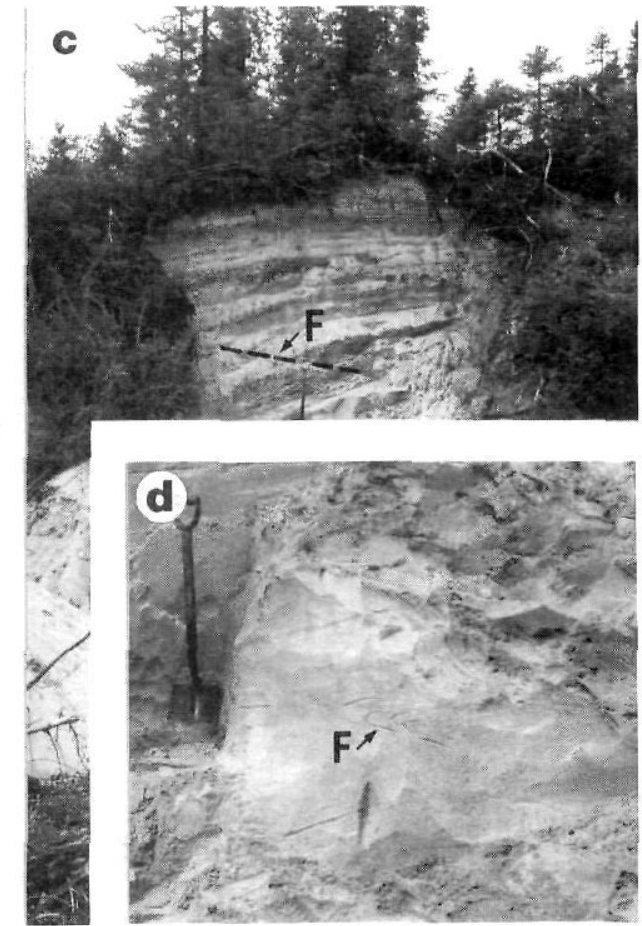

FIGURE 7. De Geer moraines composed of sorted sediments (Chapais sector): a) MO2 section. Note the till lens injected in the sorted sediments; b) ML1 bis section. Close-up on the folded and sheared foreset laminations (hammer is $39 \mathrm{~cm}$ long; $a$ and b are modified from Beaudry and Prichonnet, 1991); c) ML2 section. General view of the section; d) ML2 section. Close-up on deformation structures. Upglacier is either on the left ( $a$ and $b$ ), or on the right side (c and d). For location, see Figure 2.

Moraines de De Geer composées de sédiments triés (secteur de Chapais) : a) coupe MO2. Noter la lentille de till injectée dans les sédiments triés; b) coupe ML1bis. Agrandissement des plis et des failles déformant les lits obliques (le marteau mesure $39 \mathrm{~cm}$; $a$ et $b$ sont modifiées de Beaudry et Prichonnet, 1991); c) coupe ML2. Vue générale de la coupe; d) coupe ML2. Agrandissement des structures de déformation. L'amont glaciaire est situé à gauche (a et b) ou à droite (c et d). Voir la localisation à la figure 2 . from the till lens to the upper diamicton unit which proves that the clasts have been transported for longer distances.

\section{FACIES 2}

The second facies is represented by a non-fissile and loose till. Most of the observed sections expose this facies. This type of till occupies 75 to $100 \%$ of the sections while stratified fine or coarse sediments may form up to $25 \%$ of the entire surface. The till is sandy and its texture is similar to the underlying basal till, but it can be distinguished from the latter by its poor compactness and the absence of fissility. It contains striated boulders and clasts. Lenses and pockets of sorted sediments are frequent, but most of the moraines are structureless. Two of those sections are presented herein (Fig. 8a and b).

\section{Section 1}

The first section is illustrated on Figure $8 \mathrm{a}$. This section was cut in a moraine located $25 \mathrm{~km}$ west of Chapais (for location, see Fig. 2 and MO1A in Fig. 4). It can be separated into four principal units.

Unit $A$ is formed of a compact and fissile till containing striated clasts and rare laminations or lenses of sorted sediments. This till is interpreted as being part of the regional basal till and it is overlain by unit $B$. The contact between units $A$ and $B$ is sharp.

Unit B is composed of stratified silt and fine sand of a thickness varying from 0.2 to $1.4 \mathrm{~m}$. Ripple marks were identified in the fine sand. Paleocurrents measured on laminations of these ripple marks show that meltwaters 

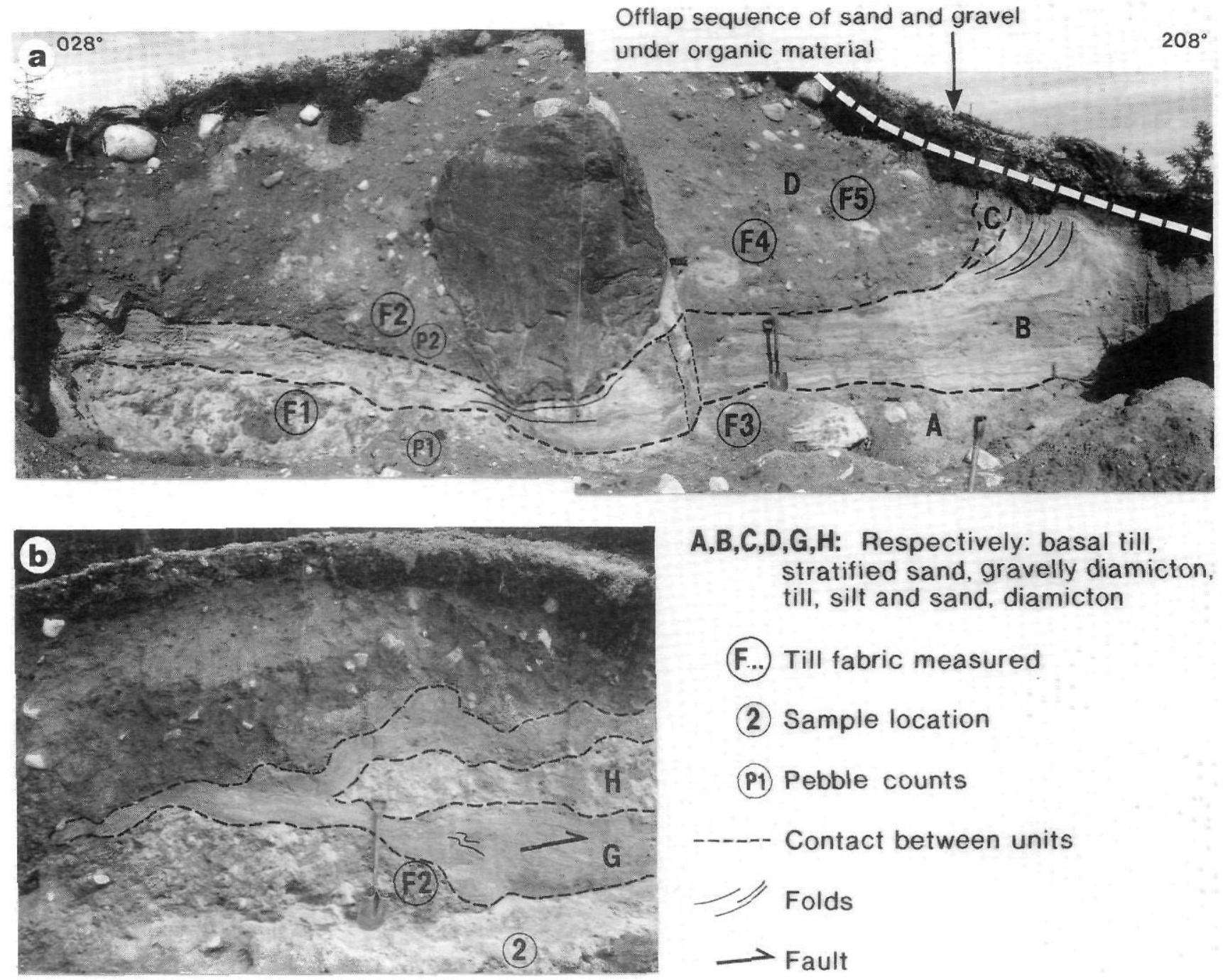

A,B,C,D,G,H: Respectively: basal till, stratified sand, gravelly diamicton, till, silt and sand, diamicton

(F... Till fabric measured

(2) Sample location

(P1) Pebble counts

FIGURE 8. De Geer moraines composed of a non-fissile and loose till. a) MO1A section (Chapais sector). General view of the section (boulder in centre of photograph is $3 \mathrm{~m}$ high): (A) basal till, (B) sorted sediments, (C) diamicton, (D) till, (F) location of till fabrics (see also Fig. 10; modified from Beaudry and Prichonnet, 1991); b) BJ1 section (Radisson sector). Close-up on the overturned syncline (see also Fig. 9a and b). Upglacier is on the left side of both sections. For location, see Figure 2.

flowed downglacier. On the distal side of the exposure, the entire unit $B$ is folded. The fold curves upwards, and it partially envelops the upper units. Under a large boulder, laminations of unit $B$ are deformed by load and drag structures. This is shown on Figure $8 \mathrm{a}$ by the variation in thickness of unit B (from only $0.2 \mathrm{~m}$ upglacier to $1.3 \mathrm{~m}$ downglacier). The fold was probably formed by the bulldozing effect of the glacier during its forward flow.

Unit B is overlain by unit C and their contact is gradational, from a fine sand to a gravelly diamicton. The thickness of unit $\mathrm{C}$ may be as little as a few centimetres, so that it can be seen only on the right side of the section. The gravelly diamicton is partially winnowed of its fine particles.

Unit $C$ grades into unit $D$ which is a till. This till may be distinguished from the basal till of unit $A$ by the absence of

Moraines de De Geer constituées d'un till peu compact et non fissile. a) Coupe MO1A (secteur de Chapais). Vue générale de la coupe (le bloc au centre a une hauteur de $3 \mathrm{~m}$ ): (A) till de fond, (B) sédiments triés, (C) diamicton, (D) till, ( $F$ ) localisation des fabriques de till (voir aussi la fig. 10; modifiée de Beaudry et Prichonnet, 1991); b) coupe BJ1 (secteur de Radisson). Agrandissement du synclinal couché (voir aussi la fig. 9a et b). L'amont glaciaire est à la gauche des deux photos. Voir la localisation à la figure 2.

fissility and poor compactness. It contains very small pockets of material winnowed of fine particles, which are concentrated in the lower part of the unit.

The sides of this section are covered by a unit of sandy gravel, absent over the crest but increasing in thickness away from it, to about one metre. This unit is part of the lacustrine and younger offlap sequence and it truncates all the underlying units, especially on the distal side of the section where laminations of unit B curve upwards. The truncation explains why the folds are not complete. In Figure $8 \mathrm{a}$, this truncation is hidden by organic material.

\section{Section 2}

The second section is illustrated on Figures $8 \mathrm{~b}$ and 9. This section was exposed in a moraine located $42 \mathrm{~km}$ 

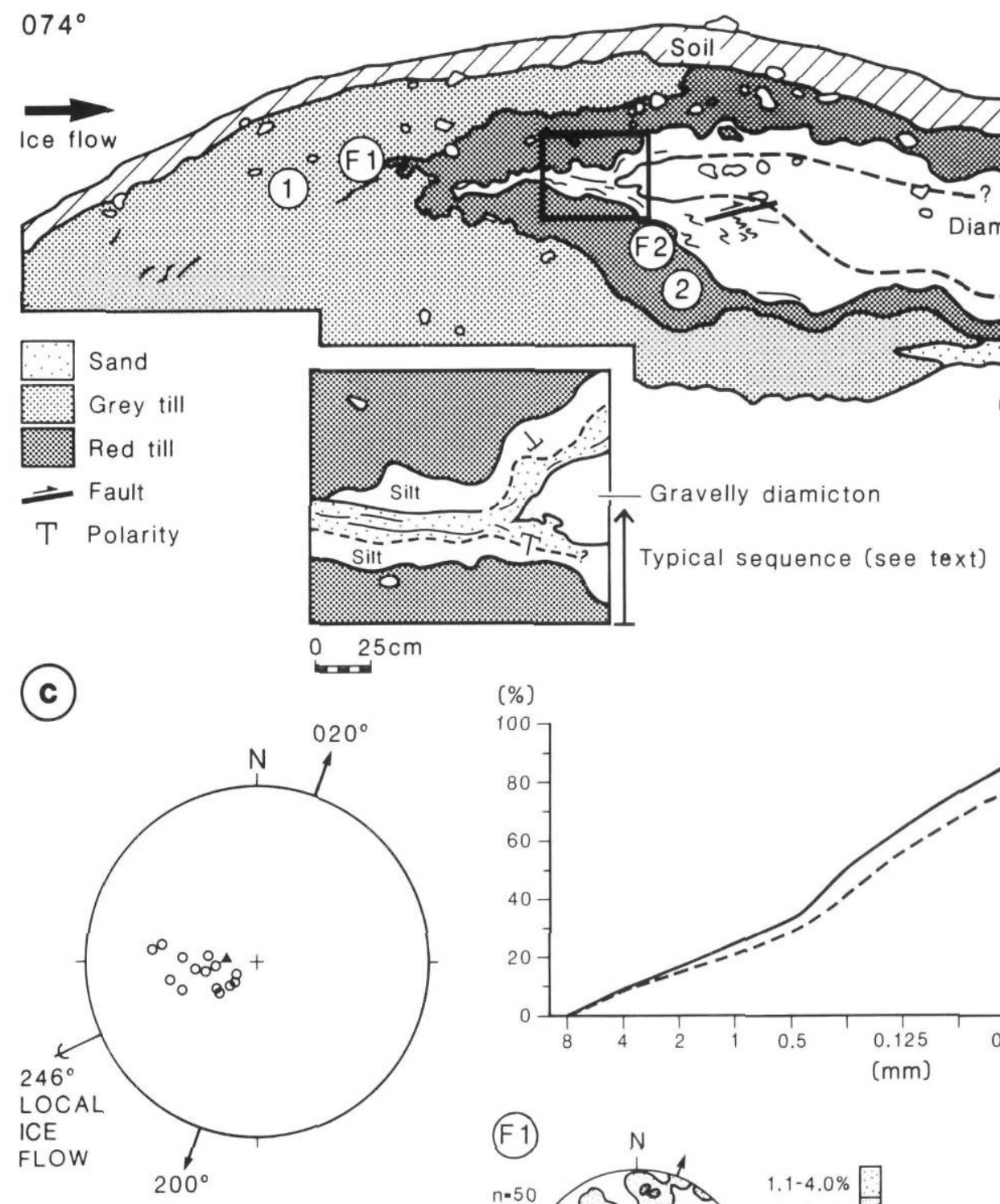

- Poles to deformed laminations in the till, $n=14$

- Pole to shear plane, $n=1$

$\longrightarrow$ Orientation of the moraine

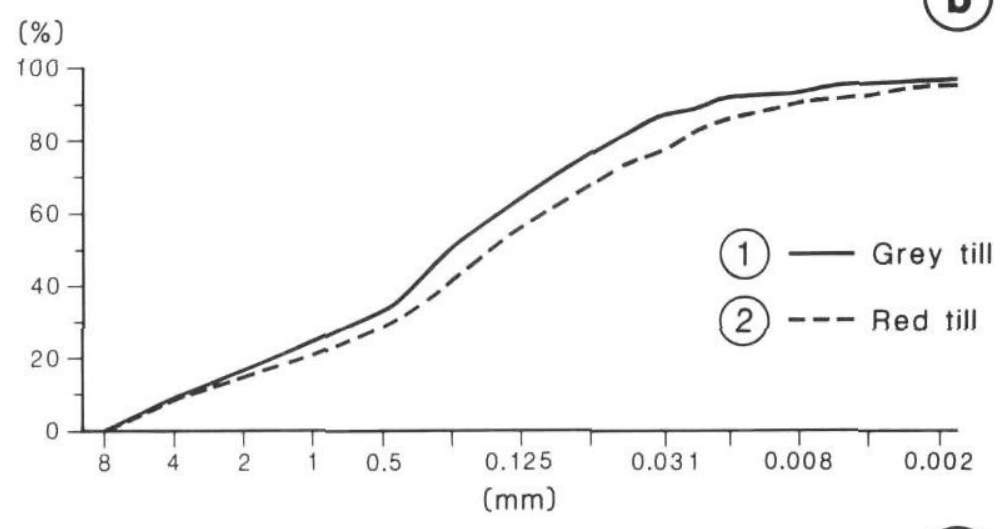

(F1)
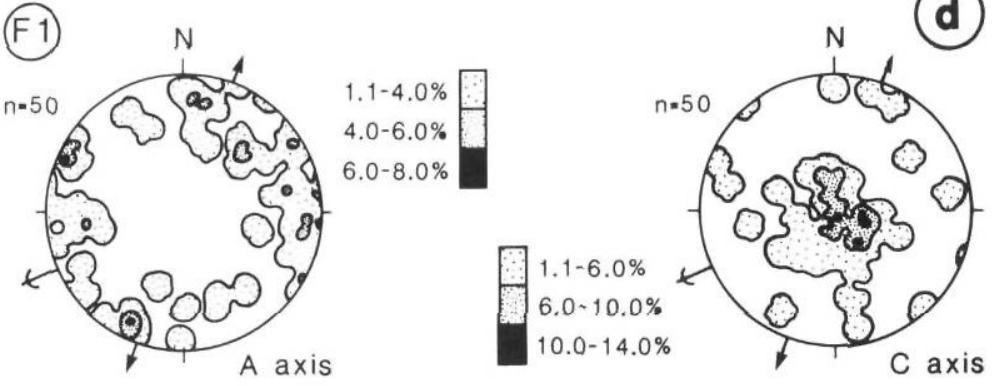

(F2)

(F... Till fabric measured
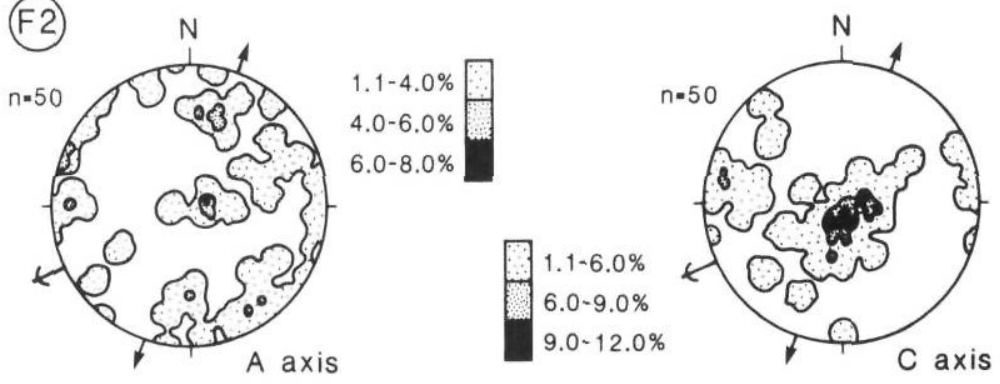

FIGURE 9. BJ1 moraine: a) schematic cross-section; b) grainsize distribution of the two tills; c) analysis of deformation structures (Schmidt equal area net, lower hemisphere); d) till fabrics (a

Moraine BJ1: a) coupe schématisée; b) granulométrie des deux tills; c) analyse des structures de déformation (canevas de axis and $c$ axis). 
southeast of Radisson (for location, see Fig. 2). It can be divided into two main units: a grey till and a complex unit consisting of four sub-units incorporated in the grey till (Fig. 8b).

At the base, the grey till is poorly compacted and non fissile. It contains dispersed striated clasts and a few laminations of sorted fine sand. These laminations are deformed and all dip upglacier. The contact between the grey till unit and the stratigraphically younger unit is sharp but irregular. This contact forms a recumbent syncline.

The second unit may be divided in four sub-units. A typical sequence of these deposits includes (Fig. 9a): (1) a reddish till $20 \mathrm{~cm}$ to $1 \mathrm{~m}$ thick. It is compact and fissile, contains striated clasts, and may have a finer texture than the grey till (Fig. 9b); (2) $25 \mathrm{~cm}$ of silt; (3) $10 \mathrm{~cm}$ of laminated sand which is folded and sheared. The axial planes of the folds are sub-horizontal. The shear plane dips upglacier and shows translocation downglacier (Fig. 9c); (4) a gravelly diamicton. This diamicton extends to the downglacier portion of the section where it contains subhorizontal laminations of sorted sediments.

This sequence is part of the syncline formed by the grey till and follows the contour of this syncline. Several features point toward an upglacier origin for those sediments: (a) the upglacier dip of the fine laminations incorporated in the grey till; (b) the similar dip of the shear plane measured on the normal face of the syncline and; (c) the evidence of translocation downglacier along this shear plane. This means that the upper face of the syncline was overturned on top of the sorted sediments of the second unit. The red till is interpreted as an allochtonous raft coming from an area located upglacier, where red quartzite outcrops are located.

\section{Similarities between the two sections and interpretation}

The two sections described above show similar sequences; however the sequence described in the Chapais area is covered by till while the sequence in the Radisson area is covered by diamicton. This difference is not significant since it can be explained by the types of deformation structures: (1) in the first moraine, the sorted sediments that form a syncline partly envelop the upper till (Fig. 8a); (2) in the second moraine, the till is deformed into an overturned syncline allowing the till to wrap the sorted sediments (Figs. $8 b$ and $9 a$ ). This difference could also be explained if the red till and the overlying sub-units of the moraine of the Radisson area were part of an allochtonous raft incorporated into the grey till.

The coarsening upward sequence described herein is not an exception, having been observed in several other moraines of the Chapais area. In the Radisson area, the scarcity of exposures precludes the determination of the extent of this type of sequence in other moraines. The coarsening upward and the gradational contacts between the units of this sequence, except with the underlying basal till, indicate a diminishing influence of flowing meltwater and an increased glacier control. That this glacier was active in the late stages of moraine formation is evidenced by the types of deformation structures and their consistent orientation (upglacier dip): load and drag structures in the intercalated sorted sediments, deformation of the laminations incorporated in the till and folds and thrust faults in the sorted sediments

\section{Lithological composition}

Four pebble counts $(0.8-5 \mathrm{~cm} ; 5-15 \mathrm{~cm})$ allow a comparison between the till composing moraines of facies 2 and the underlying basal till to be made (Table II). Five lithological classes have been distinguished: (1) volcani-clastic rocks; (2) Opémisca Pluton granitic rocks; (3) gneiss and other granites; (4) sedimentary rocks of the Mistassini Group; (5) other clasts. The volcaniclastic rocks underlie the moraines while the other lithologies are located more than $13 \mathrm{~km}$ to the northeast (Gobeil and Racicot, 1983). Note that in the 5 to $15 \mathrm{~cm}$ fraction, the gneiss and other granites also include the rocks from the Opémisca Pluton.

Two classes of lithologies are dominant (Table II): the volcaniclastic rocks (64.4 to $91.3 \%$ ) and the gneiss and other granites $(7.1$ to $27.8 \%)$. Sedimentary rocks are found in very small quantities (less than $1.9 \%$ ). In Table II, the values of the first two classes are given with brackets, calculated at a confidence level of $95 \%( \pm)$. These brackets indicate if the difference between the samples is statistically significant. The width of the brackets vary with the total clast content of the samples. Samples containing large amounts of clasts have low bracket values. Thus, the observed differences between all four moraine pebble counts are not statistically significant. Consequently, basal till and till from moraines are believed to have the same lithological composition. In three moraines, pebble counts were carried out on two fractions. In these cases, it appears that the 5 to $15 \mathrm{~cm}$ fractions always contain more volcaniclastic clasts than the 0.8 to $5 \mathrm{~cm}$ fractions. The difference is not important, but it is consistent from one moraine to the other. This points to a low maturity of the sediments.

\section{Till fabrics}

Five till fabrics have been measured in the moraine of the Chapais area (Fig. 10) and two in the moraine of the Radisson area (Fig. 9d, for location of the till fabrics, see Fig. $8 \mathrm{a}$ and Fig. 9a respectively). The $A$ and $C$ axes of 50 prolate and bladed clasts were measured in each fabric, on a vertical face of $15 \times 75 \mathrm{~cm}$. Statistical evaluation of the data has been carried out according to the method proposed by Mark $(1973,1974)$. These fabrics show that A axes have no preferential orientation: eigenvalues (S1) vary between 0.451 and 0.557 (Table III). In Figure 10, the dip of the measured clasts is generally low and they show a weak concentration oriented parallel to ice flow and another perpendicular to ice flow. In Figure 9d, the dip of the measured clasts is higher, but there is no preferential orientation. The $C$ axes are better oriented with eigenvalues (S1) between 0.571 and 0.831 . 
TABLE ॥

Lithological composition of the moraine till and adjacent basal till in the 0.8 to $5 \mathrm{~cm}$ and 5 to $15 \mathrm{~cm}$ fractions

\begin{tabular}{|c|c|c|c|c|c|c|}
\hline Moraine number & $\begin{array}{l}\text { Volcani- } \\
\text { clastics }\end{array}$ & $\begin{array}{c}\text { Gneiss } \\
\text { and other } \\
\text { granites }\end{array}$ & $\begin{array}{l}\text { Opémisca } \\
\text { granite }\end{array}$ & Ultra-distal & Others & Total \\
\hline \multicolumn{7}{|l|}{ MO1A } \\
\hline \multicolumn{7}{|l|}{$0.8-5 \mathrm{~cm}$} \\
\hline Moraine till & $68.4 \pm 4.7$ & $26.7 \pm 4.5$ & 2.7 & 1.9 & 0.3 & 370 \\
\hline Lodgement till & $68.8 \pm 4.5$ & $24.5 \pm 4.3$ & 5.1 & 1.3 & 0.3 & 395 \\
\hline \multicolumn{7}{|l|}{ MO5 } \\
\hline \multicolumn{7}{|l|}{$0.8-5 \mathrm{~cm}$} \\
\hline Moraine till & $80.4 \pm 4.5$ & $16.0 \pm 4.1$ & 2.0 & 1.3 & 0.3 & 301 \\
\hline $\begin{array}{l}\text { Lodgement till } \\
5-15 \mathrm{~cm}\end{array}$ & $83.9 \pm 3.5$ & $12.6 \pm 3.3$ & 3.2 & - & 0.3 & 397 \\
\hline Moraine till & $91.3 \pm 3.3$ & $7.1 \pm 3.1$ & - & 0.8 & 0.8 & 265 \\
\hline Lodgement till & $85.5 \pm 4.7$ & $13.5 \pm 4.5$ & - & 0.5 & 0.5 & 221 \\
\hline \multicolumn{7}{|l|}{ MO6 } \\
\hline \multicolumn{7}{|l|}{$0.8-5 \mathrm{~cm}$} \\
\hline Moraine till & $74.1 \pm 4.3$ & $19.9 \pm 3.9$ & 4.5 & 1.5 & - & 402 \\
\hline $\begin{array}{l}\text { Lodgement till } \\
5-15 \mathrm{~cm}\end{array}$ & $66.5 \pm 4.7$ & $28.6 \pm 4.5$ & 3.5 & 1.1 & 0.3 & 374 \\
\hline Moraine till & $73.2 \pm 5.5$ & $24.5 \pm 5.3$ & - & 2.3 & - & 257 \\
\hline Lodgement till & $72.3 \pm 4.5$ & $25.7 \pm 4.5$ & - & 1.2 & 0.8 & 374 \\
\hline \multicolumn{7}{|l|}{ ML1 } \\
\hline \multicolumn{7}{|l|}{$0.8-5 \mathrm{~cm}$} \\
\hline Moraine till & $74.2 \pm 4.3$ & $24.9 \pm 4.1$ & - & 0.7 & 0.2 & 406 \\
\hline Lodgement till & $64.4 \pm 4.9$ & $33.2 \pm 4.9$ & 0.8 & 0.8 & 0.8 & 356 \\
\hline \multicolumn{7}{|l|}{ MBF1 } \\
\hline \multicolumn{7}{|l|}{$0.8-5 \mathrm{~cm}$} \\
\hline Moraine till & $72.1 \pm 5.3$ & $24.7 \pm 5.1$ & 1.4 & 1.1 & 0.7 & 283 \\
\hline $\begin{array}{l}\text { Lodgement till } \\
5-15 \mathrm{~cm}\end{array}$ & $76.0 \pm 5.1$ & $19.9 \pm 4.9$ & 1.9 & 1.1 & 1.1 & 262 \\
\hline Moraine till & $77.3 \pm 5.7$ & $21.3 \pm 5.5$ & - & 1.4 & - & 216 \\
\hline Lodgement till & $75.3 \pm 6.3$ & $22.5 \pm 6.1$ & - & 1.7 & 0.5 & 182 \\
\hline \multicolumn{7}{|l|}{ MK1 } \\
\hline \multicolumn{7}{|l|}{$0.8-5 \mathrm{~cm}$} \\
\hline Moraine till & $70.4 \pm 5.3$ & $27.8 \pm 5.3$ & 0.7 & 0.4 & 0.7 & 277 \\
\hline $\begin{array}{l}\text { Lodgement till } \\
5-15 \mathrm{~cm}\end{array}$ & $77.2 \pm 4.5$ & $18.8 \pm 4.3$ & 1.9 & 0.9 & 1.2 & 324 \\
\hline Moraine till & $79.6 \pm 5.3$ & $17.3 \pm 4.9$ & - & 1.8 & 1.3 & 225 \\
\hline Lodgement till & $77.0 \pm 5.7$ & $22.0 \pm 5.7$ & - & 0.5 & 0.5 & 209 \\
\hline
\end{tabular}

\section{FACIES 3}

The third facies is represented by a fissile and compact till. Around $10 \%$ of the observed cross-sections show this facies. Sorted sediments may occupy up to $40 \%$ of the exposures, but they may also be limited to very thin laminations incorporated in the till, thus forming less than $1 \%$ of the section. The texture of the till is similar to the underlying basal till. It is sandy, compact and fissile and it contains striated clasts. The laminations of fine sorted sediments incorporated in the till and the primary sedimentary structures of the sorted sediments underlying the till of the moraine are deformed. One section is presented here (Fig. 11a).

This exposure is located $38 \mathrm{~km}$ west of Chapais (Fig. 2). The section was cut in a moraine parallel to the moraine of
Figure $7 \mathrm{~b}$. The two sections are separated by a distance of $200 \mathrm{~m}$. The section of Figure 11a can be separated into four units.

The first unit is formed of a compact and fissile till with a sandy texture (Fig. 11a, see b1). It contains striated clasts. No laminations of sorted sediments were observed in this till. It is interpreted as being part of the regional basal till.

A sand lens overlies the first unit (Fig. 11a, see b2). The contact between the two units is sharp. The sand lens occupies $40 \%$ of the exposure. It is bevelled on the proximal side and it becomes thicker below the crest of the moraine where it has a thickness of $1.2 \mathrm{~m}$. This sand lens is stratified and its primary sedimentary structures are deformed by small folds. An axial plane measured in the folds dips upglacier (Fig. 11c). On the distal side of the 
moraine, this unit is replaced by a gravelly diamicton not shown on Figure 11a. The transition between the sand lens and the gravelly diamicton has not been observed. The upper portion of the sand lens contains till pebbles.

The sand lens grades into a unit identified as a waterlain till of variable thickness (up to $70 \mathrm{~cm}$ ), thus forming a
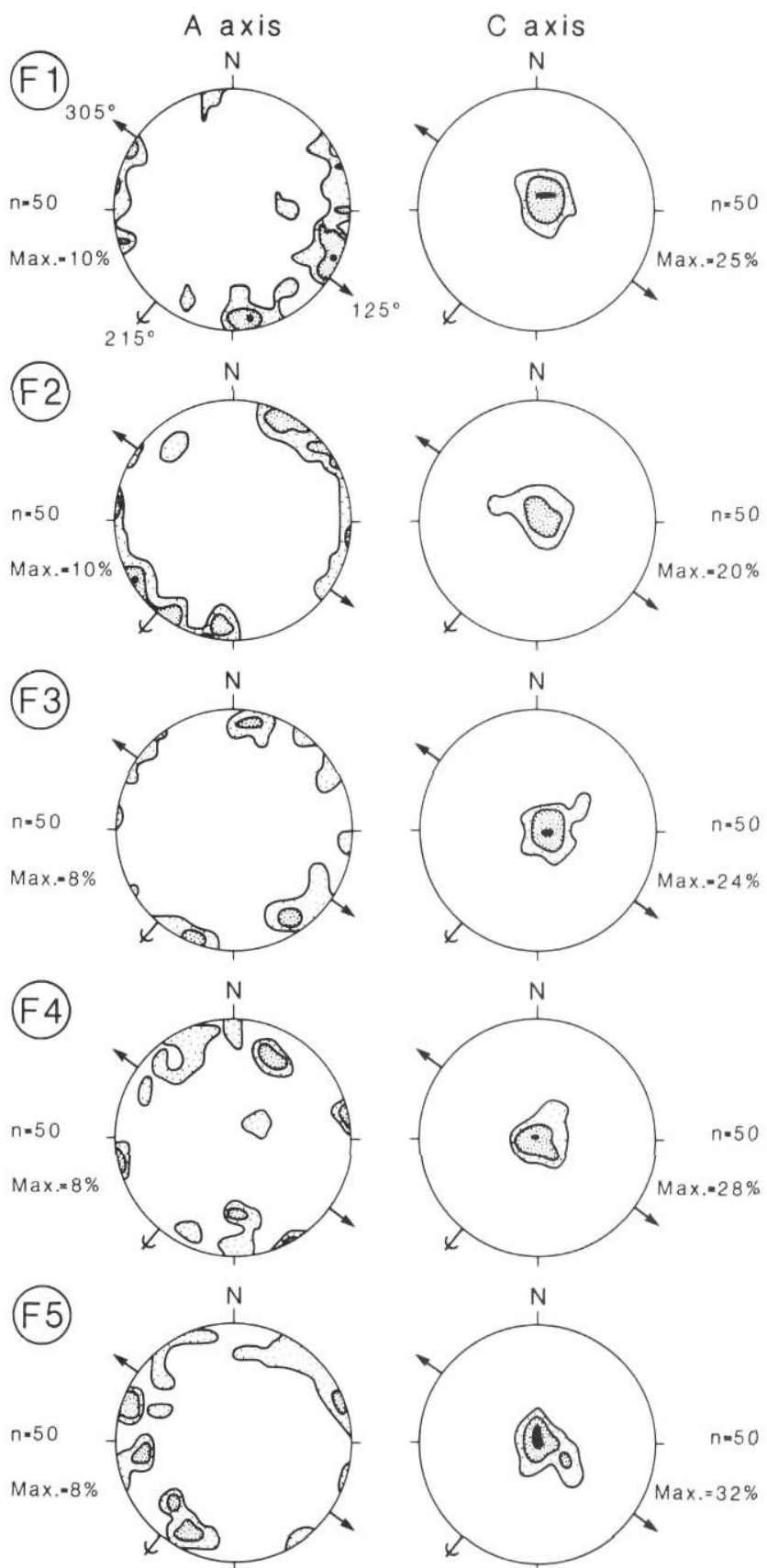

\begin{tabular}{|l}
$2-4 \%$ \\
$4-8 \%$ \\
$>8 \%$
\end{tabular}

A axis

C axis

FIGURE 10. Till fabrics of MO1A section (a axis and $\mathrm{c}$ axis). For location, see Figure 8.

Fabriques de till de la coupe MO1A (axes a et c). Voir la localisation des mesures à la figure 8 .

gradational contact. The sediments of this unit have a coarser texture than the underlying basal till (Fig. 11a, see b3). It is compact and contains striated clasts. It seems to be somewhat deficient in silt and clay particles relative to the regional till, which suggests that it was probably deposited in water. Those characteristics are typical of a waterlain till (Dreimanis, 1979).

Finally, the waterlain till grades into a upper unit of compact and fissile till with a similar texture to that of the underlying basal till (Fig. 11a, see b4). The till of the upper unit contains striated clasts, but no laminations of fine sorted sediments. The lower face of this unit and of the waterlain till dip upglacier (Fig. 11c).

\section{Lithological composition}

Two pebble counts $(0.8-5 \mathrm{~cm} ; 5-15 \mathrm{~cm})$ allow a comparison of the lithological composition of the till forming the moraines of facies 3 with the underlying basal till (Table II). Two classes are dominant: the volcaniclastic lithologies $(64.4$ to $74.2 \%)$ and the gneiss and other granites (19.9 to $33.2 \%$ ). In the fraction of 0.8 to $5 \mathrm{~cm}$, for both moraines, the till of the moraine contains significantly more volcaniclastic lithologies than the underlying basal till, this being calculated at a confidence level of $95 \%( \pm)$. With a bedrock underlying those moraines being composed of volcaniclastic rocks, this shows that the moraines containing this facies are composed of a till having a more local origin than the underlying basal till. A moraine containing locally derived debris has also been observed in the area of Lac Scott, east of Chapais (Bisson, 1987). This aspect should be investigated further because of its obvious relevance to mineral exploration.

Although the till of the moraine is composed of more locally derived debris than the underlying basal till, its composition shows the same variations as the basal till. This is seen by comparing the lithological composition of the pebble counts from moraines MO5 and MO6 (for location of the sections, see Fig. 4). The exposures cut through the two moraines parallel to one another and the sections are separated by a distance of $230 \mathrm{~m}$. The lithological composition of the basal till in these sites is quite different (Table III). In the area adjacent to moraine MO5, the local lithologies are dominant in the basal till (0.8$5 \mathrm{~cm}, 83.9 \% ; 5-15 \mathrm{~cm}, 85.5 \%$ ) while the basal till near moraine MO6 contains fewer local clasts $(0.8-5 \mathrm{~cm}, 66.5 \%$; $5-15 \mathrm{~cm}, 72.3 \%$ ). At both sites, similar variations are observed in the lithological composition of the till coming from the moraines. Thus, variations can be observed in the origin of the basal till over short distances, and the till composing the moraines tends to have similar variations in its lithological composition.

\section{Till fabric}

One till fabric was measured in the moraine of Figure 11a. The $A$ axes of the measured clasts preferentially dip upglacier (Fig. 11d). The calculated eigenvector for the $A$ axes is parallel to the last ice flow $\left(\mathrm{V} 1=035^{\circ} / 12.0^{\circ}\right)$ and its eigenvalue confirms the strong clustering of poles around this value $(S 1=0.831)$. The $C$ axes of the measured clasts 
TABLE III

Description of the till fabrics data. V1 and V3 are eigenvectors. S1 and S3 are the corresponding eigenvalues

\begin{tabular}{|c|c|c|c|c|c|c|c|}
\hline $\begin{array}{l}\text { Moraine } \\
\text { number }\end{array}$ & $\begin{array}{l}\text { Sample } \\
\text { number }\end{array}$ & $\begin{array}{c}\text { Axis } \\
\text { Measured }\end{array}$ & $\mathrm{N}$ & $\begin{array}{c}\mathrm{V} 1 \\
\text { Azimuth plunge }\end{array}$ & S1 & $\begin{array}{c}\text { V3 } \\
\text { Azimuth plunge }\end{array}$ & S3 \\
\hline M01A & $\mathrm{F} 1$ & A & 50 & $110.5^{\circ} 11.1^{\circ}$ & 0.521 & $330.3^{\circ} 76.6^{\circ}$ & 0.104 \\
\hline M01A & $\mathrm{F} 1$ & C & 50 & $045.1^{\circ} 81.1^{\circ}$ & 0.823 & $262.7^{\circ} 7.0^{\circ}$ & 0.068 \\
\hline MO1A & $\mathrm{F} 2$ & A & 50 & $041.8^{\circ} 0.7^{\circ}$ & 0.557 & $285.7^{\circ} 88.4^{\circ}$ & 0.073 \\
\hline MO1A & $\mathrm{F} 2$ & C & 50 & $025.6^{\circ} 83.4^{\circ}$ & 0.779 & $228.9^{\circ} 6.0^{\circ}$ & 0.074 \\
\hline MO1A & F3 & A & 50 & $153.0^{\circ} 7.7^{\circ}$ & 0.488 & $279.0^{\circ} 77.1^{\circ}$ & 0.096 \\
\hline MO1A & F3 & C & 50 & $054.4^{\circ} 80.7^{\circ}$ & 0.819 & $308.4^{\circ} 2.6^{\circ}$ & 0.066 \\
\hline M01A & $\mathrm{F} 4$ & A & 50 & $351.1^{\circ} 7.2^{\circ}$ & 0.489 & $152.2^{\circ} 82.4^{\circ}$ & 0.195 \\
\hline M01A & F4 & C & 50 & $077.4^{\circ} 82.8^{\circ}$ & 0.776 & $336.1^{\circ} 1.4^{\circ}$ & 0.078 \\
\hline M01A & F5 & A & 50 & $230.2^{\circ} 4.7^{\circ}$ & 0.519 & $122.4^{\circ} 74.9^{\circ}$ & 0.103 \\
\hline MO1A & F5 & C & 50 & $114.3^{\circ} 80.6^{\circ}$ & 0.831 & $225.6^{\circ} 3.5^{\circ}$ & 0.046 \\
\hline ML1 & $\mathrm{F} 1$ & A & 50 & $035.2^{\circ} 12.0^{\circ}$ & 0.807 & $244.2^{\circ} 76.4^{\circ}$ & 0.026 \\
\hline ML1 & $\mathrm{F} 1$ & C & 50 & $325.7^{\circ} 81.3^{\circ}$ & 0.876 & $206.5^{\circ} 4.3^{\circ}$ & 0.031 \\
\hline BJ1 & $\mathrm{F} 1$ & A & 50 & $068.0^{\circ} 8.4^{\circ}$ & 0.520 & $227.9^{\circ} 81.0^{\circ}$ & 0.151 \\
\hline BJ1 & $\mathrm{F} 1$ & C & 50 & $167.9^{\circ} 79.5^{\circ}$ & 0.662 & $284.0^{\circ} 4.6^{\circ}$ & 0.161 \\
\hline BJ1 & $\mathrm{F} 2$ & A & 50 & $116.5^{\circ} 22.1^{\circ}$ & 0.451 & $259.7^{\circ} 63.1^{\circ}$ & 0.204 \\
\hline BJ1 & $\mathrm{F} 2$ & C & 50 & $235.6^{\circ} 71.4^{\circ}$ & 0.571 & $359.8^{\circ} 10.7^{\circ}$ & 0.118 \\
\hline
\end{tabular}

$\mathrm{V} 1$ and $\mathrm{V} 3$ are eigenvectors; $\mathrm{S} 1$ and $\mathrm{S} 3$ are the corresponding eigenvalues

are perpendicular to the ice flow $\left(\mathrm{V} 1=325.7^{\circ} / 81.3^{\circ} ; \mathrm{S} 1=\right.$ 0.876). The clasts incorporated in the till of this moraine show a preferential orientation in the direction of ice flow, thus meaning that this till formed under an active glacier.

\section{RELATIONSHIP BETWEEN FACIES}

The spatial distribution of the three identified facies show that they grade into one another. Figure $4 \mathrm{a}$ is a surficial deposit map on which a series of at least 15 successive moraines composed of sediments of facies 1 can be recognized (glaciofluvial sediments). This series is parallel to the direction of ice flow, and Beaudry and Prichonnet (1991, fig. 2A) showed that it may be associated with an esker system located about $5 \mathrm{~km}$ in a downglacier direction.

The section illustrated in Figure 7a was dug in a moraine from this series (see MO2 in Fig. 4a). In this moraine, water played an important part in the emplacement of the landform in which sorted sediments form $80 \%$ of the section. The section of Figure $8 \mathrm{a}$ shows a facies arrangement typical of facies 2. This section is located $200 \mathrm{~m}$ north of the previous exposure (see MO1A in Fig. 4a). Here, the sorted sediments constitute only $25 \%$ of the section and the till is not fissile and is poorly compacted. Finally, another moraine located $225 \mathrm{~m}$ further north from the previous one (see MO6 in Fig. $4 \mathrm{a}$ ) is entirely composed of a compact and fissile till typical of facies 3 . This moraine is located at an elevation about 10 $\mathrm{m}$ higher than the two previous ones.

This facies relationship shows that meltwaters were probably concentrated in a sheet whose width corresponded to the length of the moraines that are part of the series of glaciofluvial moraines. Laterally, nearer facies 2, water played a less important part as is shown not only by the smaller proportion of the section occupied by sorted sediments, but also by the texture of the sorted sediments which are coarser in facies 1 than in facies 2 . Still further from the series, the role of meltwaters seems to have been even less significant. This is shown by the absence of sorted sediments in moraine MO6.

\section{THE MODEL}

The proposed model is illustrated on Figure 12. Part of this model has been presented in an earlier paper discussing of De Geer moraines composed of stratified sediments (Beaudry and Prichonnet, 1991, fig.11). It is suggested that series of De Geer moraines were emplaced simultaneously into bottom crevasses located up to a few hundred metres behind the ice front. No attempt is made to suggest a model that could explain the genesis of all De Geer moraines since it is recognized here that different processes may lead to the development of similar landforms.

\section{GENERAL GLACIAL CONTEXT}

Deglaciation in the Chapais area occurred around 8300 BP (Hardy, 1976). The Nouveau-Québec Glacier was then in contact with Glacial Lake Ojibway (Fig. 2). Norman (1938) established the maximum lake level at $438 \mathrm{~m}$ near Chapais, Ignatius (1956) proposed a level of $427 \mathrm{~m}$ southwest of Chibougamau, while Prichonnet et al. (1984) suggested a level of at least $445 \mathrm{~m}$ east of Chibougamau. The exposure by Norman (1938) is located west of Lac Opémisca and is thus nearer the moraines described herein. The water depth would then have been about $80 \mathrm{~m}$ when these moraines were emplaced.

In the Radisson area, deglaciation occurred when the glacier was first in contact with Glacial Lake Ojibway, to the west of the actual Sakami Moraine position, and then in contact with the Tyrrell Sea, east of the moraine (Fig. 2). De Geer moraines of the Radisson sector developed only when the Nouveau-Québec Glacier was in contact with the 

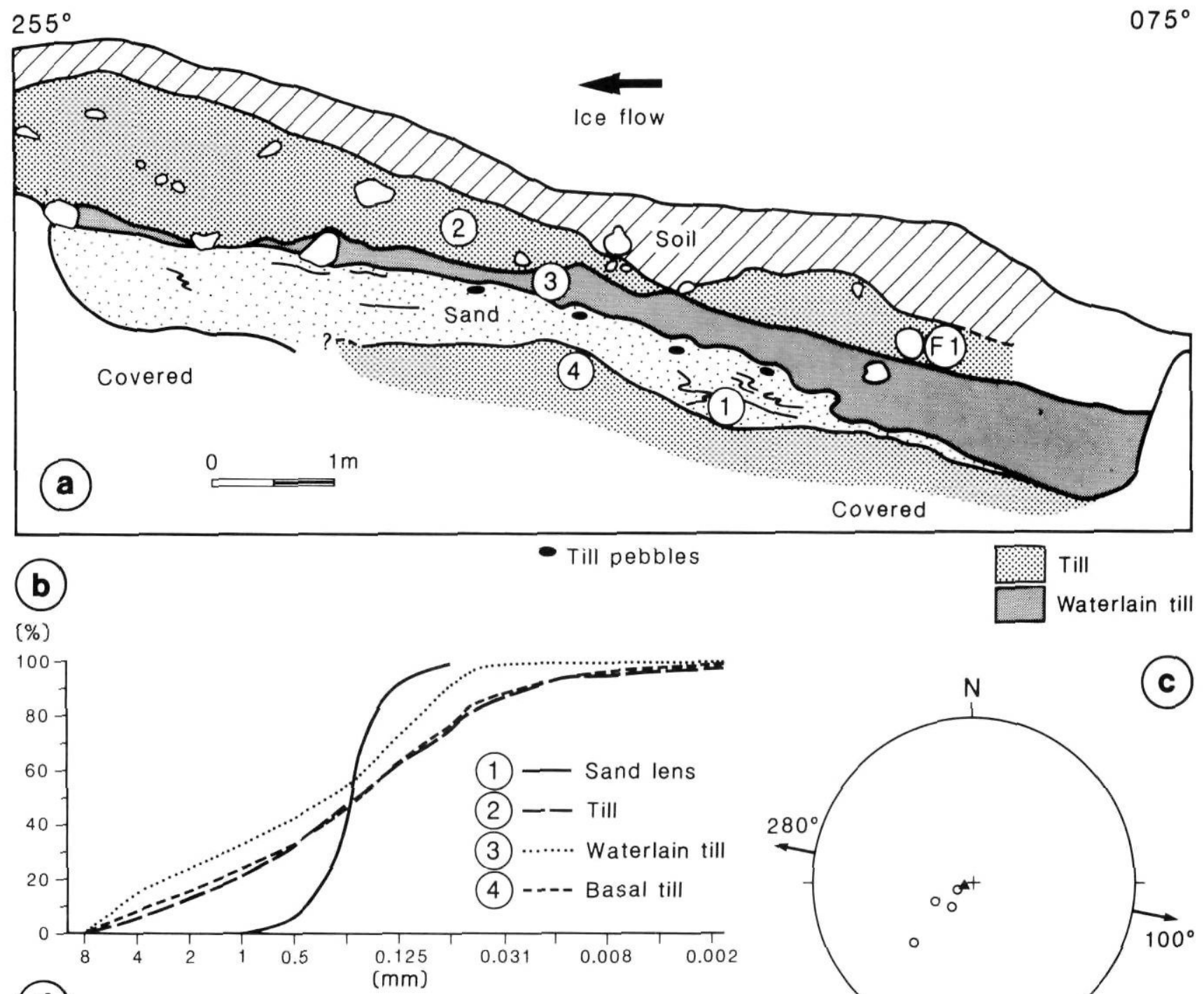

(d)

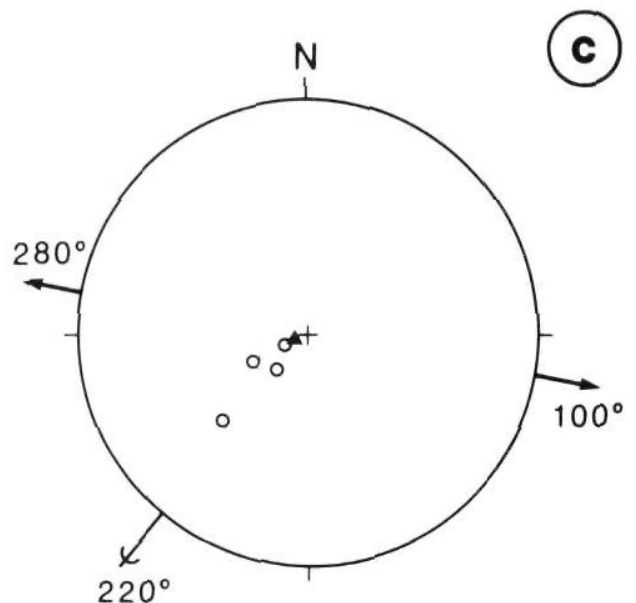

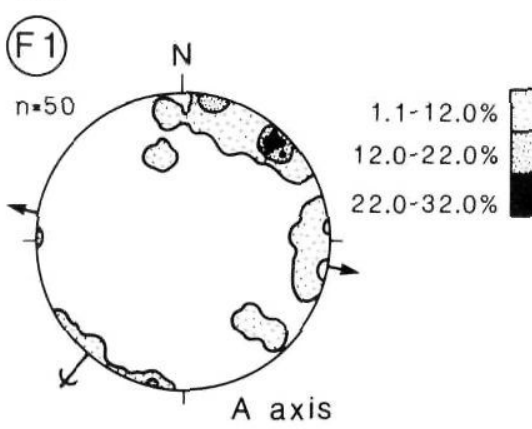

FIGURE 11. ML1 section: a) schematic cross-section; b) grainsize distribution of the four units; c) analysis of deformation structures (Schmidt equal-area net, lower hemisphere); d) till tabric (a axis and $\mathrm{c}$ axis). Upglacier is to the right. For location, see Figure 2.
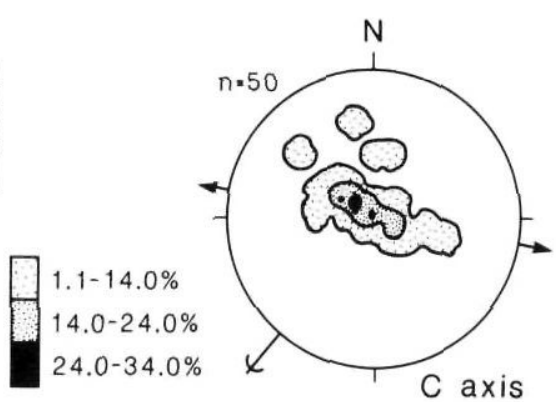

LCAL

ICE FLOW
- Pole to axial plane, $n=1$

- Poles to sand/till contacts, $n=4$

$\rightarrow$ Orientation of the moraine
Coupe ML1: a) coupe schématisée ; b) granulométrie des quatre unités; c) analyse des structures de déformation (canevas de Schmidt, hémisphère inférieur); d) fabrique de till (axes a et c). Voir la localisation à la figure 2. 
Tyrrell Sea whose minimum depth varied from $55 \mathrm{~m}$ over topographic highs to $115 \mathrm{~m}$ in valleys (Vincent, 1977). No De Geer moraines were apparently deposited west of the Sakami Moraine. Lake Ojibway was probably too deep for the moraines to form (Hardy, 1976; Vincent, 1977). In fact, Hardy (1976) proposed that no De Geer moraines were deposited in areas where the lake was deeper than $180 \mathrm{~m}$.
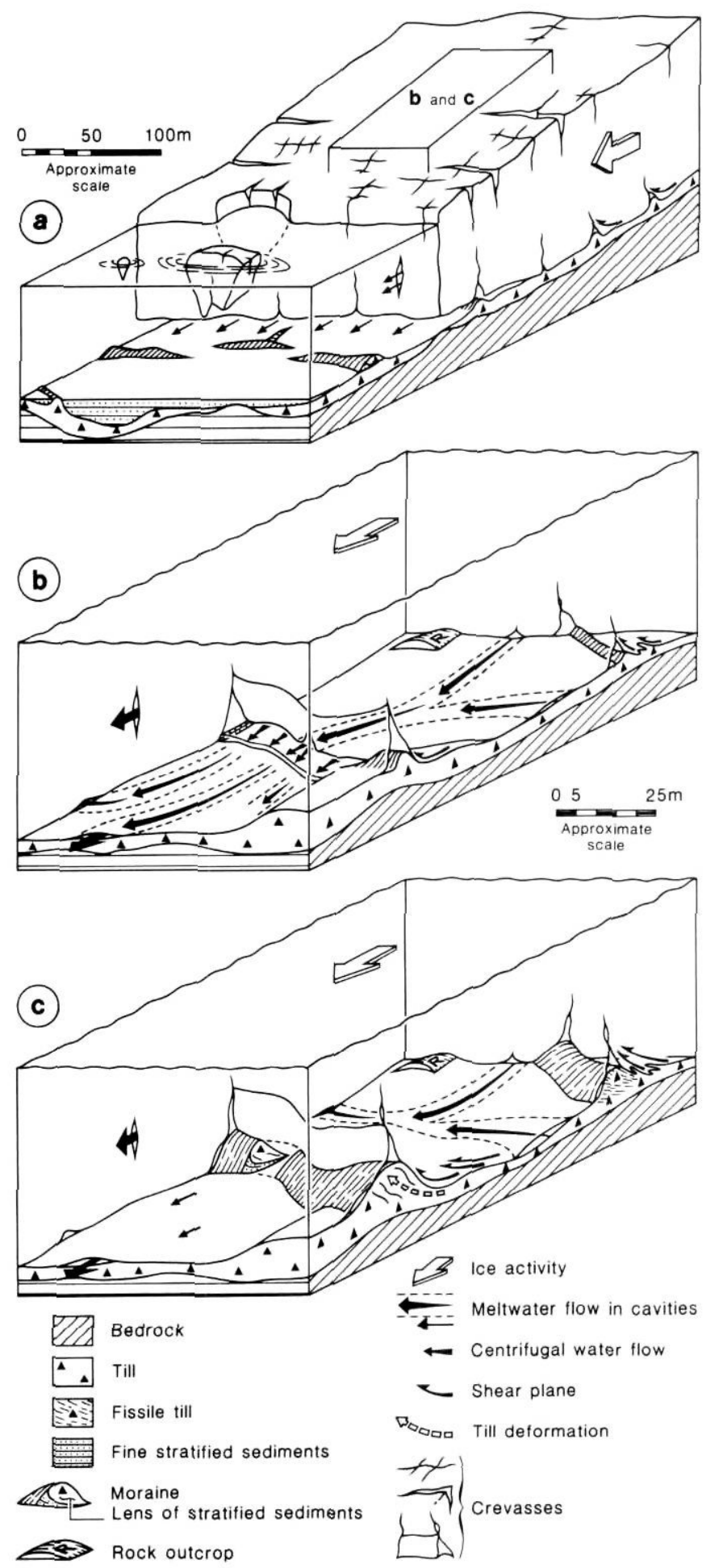

\section{GENESIS OF THE STUDIED MORAINES}

\section{Opening of the bottom crevasses}

The Nouveau-Québec Glacier was in contact with large bodies of water such as Glacial Lake Ojibway or the Tyrrell Sea. It is expected that the glacier terminus would be somewhat buoyant. Seasonal increases in water levels or tides could have generated even more buoyancy. This buoyancy would have increased the tensile stress at the glacier grounding line. Herterich (1987, fig. 11) presented a model for the calculation of the stresses. They were calculated over the entire ice column within the transition zone between a grounded glacier and an ice shelf. Behind the grounding line, the buoyancy would cause compressional stresses near the glacier's surface and tensile stresses near the base of the glacier. Using this model, Herterich predicted that, in response to those tensile stresses, open bottom crevasses should be created behind the grounding line.

Bottom crevasses forming in this context have been identified inside Ice Stream B and the Ross Ice Shelf, in Antarctica by Jezek and Bentley $(1979,1983)$. These authors have demonstrated the existence of a system of crevasses perpendicular to ice flow and a second system of smaller crevasses crosscutting the first. Jezek and Bentiey (1983) suggested that the crevasses are caused by the effect of tension in the ice, related to its buoyancy or by shear stresses between fast moving outlet glaciers feeding zones of slower moving ice.

It is proposed that the opening of bottom crevasses in the Nouveau-Québec Glacier, fringing a large body of water, would have been caused by the buoyancy of the glacier terminus. The series of bottom crevasses would have opened, behind the grounding line, in response to the basal tensile stresses such as those predicted in Herterich's (1987) model. Seasonal variations of water levels in Glacial Lake Ojibway or tidal variations in the Tyrrell Sea would enhance this process. It is even possible that these

FIGURE 12. Model for the emplacement of De Geer moraines. Note that the surface of diagrams $b$ and $c$ do not represent the upper surface of the glacier: a) general glacial context. The terminus of the glacier is slightly buoyed up by the frontal water body. Crevasses open because of the stress created by the buoyancy at the grounding line; b) opening of the crevasses and initiation of the deposition phase by deformation of the basal till and squeezing. In areas of channelled meltwater flow, sorted fine sediments accumulate in crevasses (see Beaudry and Prichonnet, 1991, fig. 11); c) accumulation of till and deformation of the sorted sediments. Meltwaters flow elsewhere.

Modèle de mise en place des moraines de De Geer. Noter que la surface des diagrammes $b$ et $c$ ne représente pas la surface réelle du glacier; a) contexte glaciaire général. La marge glaciaire est légèrement soulevée par le plan d'eau frontal. Les crevasses s'ouvrent le long de la ligne d'ancrage sous l'effet des tensions créées par le soulèvement; b) ouverture des crevasses et début de la phase de mise en place par déformation du till de fond et accrétion. Dans les zones où les eaux de fonte sont canalisées, des sédiments fins triés se sont accumulés dans les crevasses; c) accumulation de till et déformation des sédiments triés. Les conduits d'eau de fonte étant déstabilisés, les eaux s'écoulent ailleurs. 
variations in water levels would be the main process responsible for the increase in tensile stresses necessary for the opening of the series of bottom crevasses. It is believed here that the glacier was under an extended flow regime rather than a compressive flow regime since the latter would have closed the crevasses.

The transition between De Geer moraines and Rogen moraines (Fig. 6) and the moraines curving upglacier near a steep slope (Fig. 3c) also support a genesis in bottom crevasses. The slopes may have caused extended flow and the subsequent opening of bottom crevasses (Sugden and John, 1976). In these two examples, the moraines are not perpendicular to the ice flow as deduced from surrounding linear landforms. They are in fact oblique to the ice flow, a pattern expected for crevasses forming under extended flow (Vornberger and Whillans, 1990, fig. 7).

The geomorphology of the moraines and their spatial distribution may be explained by deposition in a system of bottom crevasses rather than by emplacement at the ice front. The development of angularity in the main moraine segment (Prichonnet et al., 1984, fig. 17; Figs. 3 and 4), of oblique to perpendicular appendages and of a grid net pattern (Fig. 3d) would be the result of the original spatial distribution of the crevasses. Jezek and Bentley (1979, fig. 10) have identified such patterns in the bottom crevasses of Ice Stream B in Antarctica. Beaudry and Prichonnet (1991) stressed that the moraines composed of stratified sediments had to have been formed in bottom crevasses. It is believed that if the moraines had been emplaced at the ice front, they would not have produced sharp crested moraines such as the ones described herein. It is expected that the sediments would rather have formed small linear accumulations extending in the direction of the ice flow in the same manner as the large eskers of the area (Prichonnet et al., 1984). The morphology of the short esker of Figure $3 e$ suggests that it resulted from the coalescence of a series of De Geer moraines forming simultaneously in at least six successive bottom crevasses. The length of this esker also suggests that crevasses opened at least up to a distance of $1 \mathrm{~km}$ behind the ice front.

\section{Emplacement of the moraines into bottom crevasses}

The proposed emplacement of the moraines is based on facies analysis and on spatial distribution. Beaudry and Prichonnet (1991) have suggested that De Geer moraines composed of sediments from facies 1 were formed in bottom crevasses, in areas where meltwaters were channelized. Those meltwaters probably flowed into subglacial channels and/or through small conduits into the lower column of ice. This could correspond to the linked cavity system of Fowler's theory (Kamb, 1987; Fyfe, 1990). The subglacial channels could also correspond to the ones presented in the model of the drainage system, inside the ablation zone of the ice sheet, proposed by Brodzikowski and Van Loon (1987, fig. 17; 1991, fig. 133). The channel widths probably corresponded to the length of the moraines forming these series. For example, in Figure 4, the width of the channel where De Geer moraines composed of glaciofluvial sediments were emplaced must have been at least $400 \mathrm{~m}$. The subglacial channels were probably located in low-lying areas since most of the series of moraines were found in these areas. The subglacial channels were probably too small and the sedimentation phase too short to allow the formation of a continuous esker such as the one identified $5 \mathrm{~km}$ downglacier from the series of moraines of Figure 4 (Beaudry and Prichonnet, 1991, fig. 2A). But in other cases, the sedimentation phase was long enough for the moraines to coalesce into an esker (for example see Fig. 3e).

The present model proposes that meltwaters flowed perpendicularly to the elongation of the crevasses as evidenced by stratification. Before entering the crevasses, meltwaters flowed under pressure and thus transported a load of sediments. When it entered into the crevasses, their velocity was diminished. This allowed the deposition of sorted sediments into foreset laminations dipping downglacier (Beaudry and Prichonnet, 1991, fig. 11A). Meltwaters probably escaped downglacier, through a subglacial channel. Since the ice was active, the pressure again increased and sediments were transported to the next crevasse located downglacier. Sorted sediments then accumulated simultaneously in series of parallel crevasses, in a downglacier direction, thus forming series of De Geer moraines composed of stratified sediments (Fig. 4). The sedimentation phase probably ended upon migration of the subglacial channels, their closure by ice activity or upon calving of that section of the glacier.

During the sedimentation phase or shortly after, the glacier still being active, the upglacier wall of the crevasse probably came into contact with the morainic sediments. This together with the forward movement of the glacier partially deformed the primary sedimentary structures. Till and/or diamicton were then deposited as a surficial cover on the proximal side, or as lenses injected into the sorted sediments. This model differs from Smith's (1982) who proposed that similar moraines were formed by bulldozing at the ice front.

Laterally from the subglacial channels, in areas where meltwater activity was decreasing, less debris could be sorted and the glacier built moraines mainly composed of till (Fig. 12b and c). Those moraines correspond to facies 2. Near the subglacial channels, or in areas where meltwaters flowed in thin sheets, fine sediments accumulated into horizontal laminations inside bottom crevasses, thus covering the basal till (Fig. 8a). These laminations have the characteristics of sediments deposited in more or less stagnant water (Brodzikowski and Van Loon, 1987). When, subsequently, the glacier came into contact with the bed, a surficial layer of the basal till was deformed and remobilized. This till was transported in a downglacier direction, toward basal crevasses. When the till began accumulating in the crevasses, the influence of meltwater decreased. This is shown by the vertical transition from sorted sediments occasionally containing till pebbles (Fig. 11a), into a coarse diamicton winnowed of its fine particles, and finally into a true till (Fig. 8a). The chaotic aspect of the till fabrics (Figs. $9 \mathrm{~d}$ and 10) show that this till was not emplaced in direct 
contact with the active glacier. As this loose till was deposited, the underlying sorted sediments were deformed by fold, load and drag structures. Here again, the glacier was active and it deformed the sorted sediments and the overlying till. This deformation was probably generated by the contact of the upglacier wall of the crevasse with the morainic sediments.

Till deformation has been inferred by seismic analysis of conditions at the bottom of Ice Stream B in Antarctica (Alley et al., 1986, 1987; Blankenship et al., 1986; Menzies, 1989). Hart and Boulton (1991) observed that subglacial deformation is not unusual. The thickness of till affected by the deformation processes may reach six metres. This till is interpreted to be water-saturated and plastic (Menzies, 1989).

Based on the till fabric data, it appears that the till was probably extruded into cavities. Analysis of the deformation structures show that the glacier was active and that the till was moving in the direction of ice flow.

This model may also explain the scarcity of drumlins in areas where De Geer moraines are numerous (Fig. 5). Not all drumlins would have been deformed by the glacier to form De Geer moraines, but it clearly appears that some of them had their profile modified and sometimes truncated (Figs. 3a and b, 4a and b) and their material pushed downglacier to form a moraine.

In other sectors meltwater activity was more moderate so that it had a minor effect. Here, moraines of facies 3 were emplaced. Some sorted fine sediments may have been deposited (Fig. 11a), but till was more often deposited directly over the basal till. The mechanism of deposition for the till composing these moraines probably involved many processes (Fig. 12). Part of this till could have been deposited by deformation and remobilization of the surficial portion of the basal till sheet as proposed for moraines of facies 2. However, overconsolidation of the till and its fissility indicate subglacial deposition (Krüger, 1979). Subglacial deposition is also evidenced by the strong fabric (Fig. 11d). These factors suggest an accumulation mechanism where lodgement and basal melt-out predominated.

The emplacement of moraines in bottom crevasses may seem difficult to prove since it is often believed that those crevasses tend to close rapidly. But the formation of moraines composed of till has been identified inside bottom crevasses of the McBride and Plateau Glaciers in Alaska (Goldthwait, 1974; Mickelson and Berkson, 1974). Rhombohedral ridge patterns located in front of the Brásvellbreen Glacier on Svalbard have also been related to a squeezingup of till inside bottom crevasses (Solheim and Pfirman, 1985).

\section{COMPARISON WITH OTHER MODELS}

Several models have been proposed to explain the formation of De Geer moraines. In a detailed review of those models, Beaudry (1988) grouped them according to their position relative to the ice front: 1) in several papers, it was proposed that De Geer moraines were formed at the ice front or a few metres behind, where it was buoyed up by the hydrostatic pressure of the frontal water body; 2) other authors argued that the moraines were emplaced into bottom crevasses. All those models, except for the ones of Beaudry and Prichonnet (1991) and Larsen et al. (1991), were based mainly on geomorphology and till fabric analysis. Little attention was given to facies analysis. In the present model, facies analysis is used to identify the processes responsible for the emplacement of the sediments and the processes active subglacially.

The proposed mechanism of crevasse formation differs from Zilliacus' (1987a and b, 1989) model. This author suggested that the crevasses opened during Scandinavian Glacier surges. In the Chapais and Radisson areas, no evidence of surges was identified in the sectors where De Geer moraines are found. The only known surges are the Cochrane and Rupert surges in the James Bay Lowlands (Hardy, 1976), and a surge following drainage of Lake Ojibway, at the south end of Lake Mistassini (Bouchard, 1980; Dilabio, 1981). It is believed here that the crevasses opened in response to stresses caused by the buoying up of the glacier by the frontal water body, such as is proposed for Ice Stream B in Antarctica (Jezek and Bentley, 1979, 1983; Herterich, 1987).

The moraines described here could not have been formed by a short re-advance of the glacial terminus as described by Andrews and Smithson (1966), Smith (1982), Sollid and Carlsson (1984) and Larsen et al. (1991). Such a mechanism would have deformed all primary sedimentary structures, especially in those De Geer moraines composed of stratified sediments. Instead, in the studied moraines, deformation structures are restricted to sediments located just below the crest and near injected lenses of till or diamicton. This suggests that the deformation structures resulted from a minor push by the upglacier wall of the crevasse.

The present model does not require accumulation by flow of water-soaked till toward the ice terminus (Hoppe, 1957, 1959; Loken and Leahy, 1964). The morphology of the moraines such as angularity of the segments, presence of appendages and grid-net patterns, rather suggests that the till flowed toward bottom crevasses in which the sediments have been moulded. In fact, morphology of the moraines corresponds closely to the reconstructed patterns of bottom crevasses inside Ice Stream B, in Antarctica (Jezek and Bentley, 1979, fig. 10).

The hypothesis that the moraines were formed by accumulation, at the base of an ice cliff, of debris released by melting ice (Norman, 1938; Shaw, 1944; Holdsworth, 1973; Barnett and Holdsworth, 1974) can be rejected based on the facies data described above. Sediments falling from the ice cliff, into water, would probably have been somewhat sorted. Moreover, material coming from higher positions in the ice column has usually been transported over longer distances than the material coming from a basal position (Shilts, 1976). The moraines examined here are composed of a till having a similar granulometry and lithological composition to that of the underlying basal till. In addition, 
some moraines contain more local lithologies than the basal till (Table II). This suggests that the sediments were derived from the basal part of the ice column.

The mechanism for moraine deposition proposed by Mawdsley (1936) for the Opawica-Chibougamau area cannot be applied to the moraines presented here. The primary sedimentary structures and the deformation structures imply genesis by remobilization of part of the till sheet and its movement toward bottom crevasses rather than accumulation of debris washed into open crevasses.

Andrews (1963a and b) and Andrews and Smithson (1966) suggested that their simple-linear and S-shaped moraines were formed by injection of water-soaked till into bottom crevasses. Their proposed mechanism is very similar to the one suggested here.

Zilliacus (1987a and b, 1989) suggested that the moraines were emplaced in bottom crevasses by flowage of till from both sides of the crevasses. He based his conclusions on the till fabrics analysis showing that clasts dip in accordance with both slopes of the moraines. In the present study, all deformation structures (folds, thrust faults, load and drag structures) show that the till originates from the upglacier side of the crevasses only. This is also supported by the truncated drumlins of Figures $3 \mathrm{a}$ and $4 \mathrm{~b}$ which suggest that the drumlins were deformed and their material transported downglacier to form a moraine.

\section{DISCUSSION}

\section{THE ANNUAL MORAINE HYPOTHESIS}

Much of the discussion by previous authors concerning the genesis of De Geer moraines focused on their value as relative geochronological markers. This idea is based on their distribution which suggests a regular, although sporadic, mechanism of deposition. Many authors have supported an annual rate of deposition for the moraines (Norman, 1938; Shaw, 1944; Sollid and Carlsson, 1984; Larsen et al., 1991) while others rather suggested a more erratic phenomenon (Hoppe, 1957, 1959; Strömberg, 1965). Most of the recent studies on De Geer moraines propose simultaneous deposition of many successive moraine segments (Zilliacus, 1987a and b, 1989; Beaudry, 1988; Beaudry and Prichonnet, 1991).

Based on geomorphological data, Boulton (1986) proposed that push-moraines emplaced in a marine environment were probably deposited annually at the ice front. In this paper, the geomorphology of the moraines and their facies suggest that the moraines were deposited simultaneously into a series of bottom crevasses extending at least $1 \mathrm{~km}$ behind the ice front. It is believed here that the studied De Geer moraines were not deposited annually and that this landform should not be used as relative geochronological marker.

In Scandinavia, Strömberg (1965) and Zilliacus (1987a and b, 1989) compared the spacing of De Geer moraines to the established varve chronology for their area. Both authors concluded, based on their comparison, that De Geer moraines are not annual landforms. No varve chronology is available in the areas studied here, but Bouchard (1980) studied two sites located $42 \mathrm{~km}$ northeast of Chapais and $40 \mathrm{~km}$ NNE of Chapais respectively, within the basin of Glacial Lake Ojibway. He calculated a maximum annual retreat of the ice front of 200 and $330 \mathrm{~m}$ respectively. The average distance between successive De Geer moraines in the Chapais area $(180 \mathrm{~m})$ is too different from these values. Based on this comparison and on the present model, it is concluded that De Geer moraines cannot be considered annual. Even if the distance between De Geer moraines was similar to the calculated annual retreat of the ice front, this cannot be considered as being conclusive since it appears that the moraines are deposited in series of irregularly spaced basal crevasses and not at the ice front.

\section{DE GEER MORAINES IN GLACIAL LANDFORM SUCCESSIONS}

Subglacial landforms, and especially their succession in glacial landscapes give a good idea of conditions that prevailed under the last continental ice sheets (Sugden and John, 1976; Menzies and Rose, 1989). In Canada, models of glacial landscapes have been proposed for the Keewatin Ice Divide (Aylsworth and Shilts, 1989a, b) and for the Nouveau-Québec Ice Divide (Bouchard, 1989). De Geer moraines cover extensive areas of those regions, but they are not included in the succession. This could be explained by the poor understanding of the processes responsible for their formation and also by the fact that many authors still consider them as frontal and annual moraines. One attempt was made in Québec to include De Geer moraines in such a succession (Gray and Lauriol, 1985). De Geer moraines were identified as the end member of the succession and the authors correlated these landforms with the hummocky moraine member of the succession proposed by Sugden and John (1976).

One difficulty related to the position of De Geer moraines in the glacial landscape succession is that they are associated with different landforms. In the Northwest Territories, De Geer moraines are located in the outer drift zone and in the ribbed moraine zone of Aylsworth and Shilts (1989a, b). In Québec, these moraines cover very extensive areas of the outer streamlined zone of Bouchard (1989). They are also found in close association with esker systems (see Beaudry and Prichonnet, 1991) and are transitional to Rogen moraines.

De Geer moraines are often associated with drumlin fields. In drumlins the material is more easily remobilized than in the surrounding basal till sheet. It does not mean that all drumlins would have been deformed into De Geer moraines. Zones of bottom crevasses were probably formed and separated by sectors with few or no bottom crevasses.

The identified transition between De Geer moraines and Rogen moraines east of Chapais (Fig. 6) could probably have been observed in other basins where Rogen moraines formed. But the absence of a frontal water body or the presence of a water body too shallow relative to the ice thickness precluded the preservation of De Geer moraines 
so that only Rogen moraines are seen. The sequence of Figure 6a therefore suggests: (1) that the frontal water body modifies the dynamic of the glacier since calving favors a rapid retreat of the ice front; (2) that the glacier was still active when the landforms were emplaced.

This transition can only be observed near the eastern edge of Glacial Lake Ojibway where water was too shallow for crevasses to be opened by the process described in the model. Instead, the Chapais area is located well within the glaciolacustrine basin (Fig. 2). There, with deeper lacustrine waters only De Geer moraines could form. Bottom crevasses would have opened according to the mechanism proposed in this paper. Thus, the transition between $\mathrm{De}$ Geer moraines and Rogen moraines of the Chapais area would result from processes induced by the depth of the lake waters or processes where the bedrock topography is the predominant factor.

Based on the above discussion, it is proposed that De Geer moraines should be included in the glacial landscape model of Sugden and John (1976, fig. 13.16) as being part of at least the last four end members (Fig. 13). De Geer moraines would replace these end members in areas where a frontal water body would have influenced the dynamic of the glacier margin.

Another question is raised by the fact that in large areas of Québec, the Nouveau-Québec Glacier retreated in contact with frontal water bodies and yet no De Geer moraines apparently formed. Such is the case in Ungava Bay, in the James Bay Lowlands west of the Sakami Moraine, and in most of the Champlain Sea basin. In those areas, the depth of the water body relative to ice thickness probably controlled the dynamic of the glacier and no De Geer moraines were deposited. If the glacier ice is too thick compared to the water depth, the glacier cannot be buoyed up and no bottom crevasses can form. Moreover, in sectors where water was too deep relatively to glacier thickness, rapid ice flows occurred, thus precluding the preservation of bottom crevasses. A similar situation would be expected in areas where ground slope is too high.

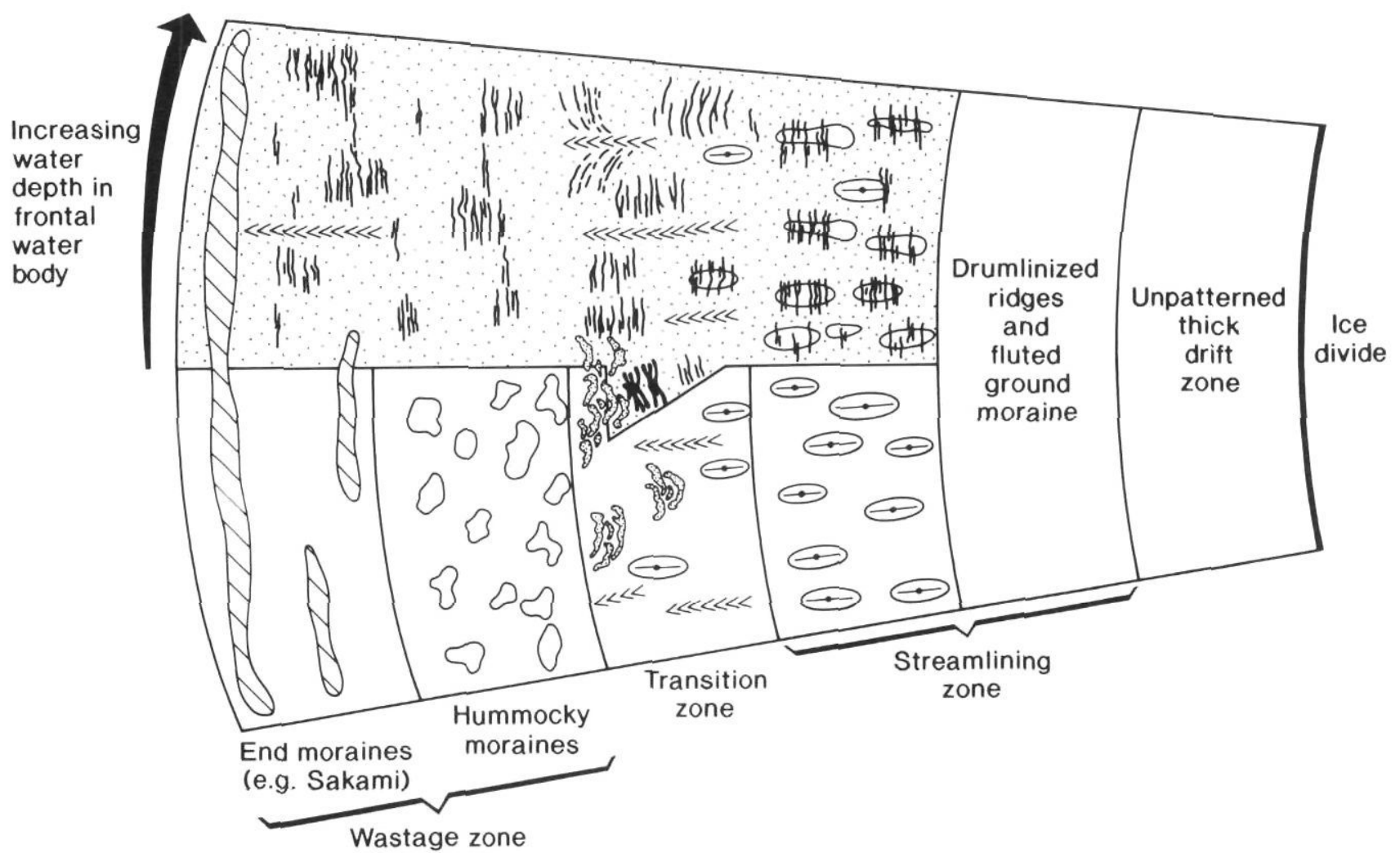

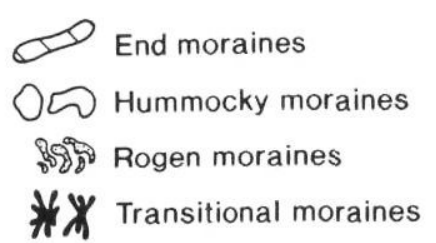

FIGURE 13. Model illustrating the place of De Geer moraines in the glacial landforms succession (modified from Sugden and John 1976, and Bouchard 1989).

\author{
W De Geer moraines \\ 臰 Drumlins cut by De Geer moraines \\ $\Leftrightarrow$ Drumlins \\ « Eskers
}

Modèle illustrant la place des moraines de De Geer dans la succession des formes glaciaires (modifié de Sugden et John, 1976 ; Bouchard, 1989). 
In summary, it is believed that frontal water bodies have a large influence on the glacier's dynamics, and that De Geer moraines form in favourable dynamic conditions. In order to better understand those processes, more research should be done in the transition zones such as the one illustrated in Figures $6 \mathrm{a}$ and 13. This should lead to a better understanding of the dynamics of the glacier, and allow the actual position of De Geer moraines in the glacial landscape succession to be better defined.

\section{CONCLUSIONS}

The present paper, based in large part on facies and deformation structure analysis, provides new insight into the genetic processes involved in the emplacement of De Geer moraines from the Chapais and Radisson areas. Geomorphological data emphasize the relationship between De Geer moraines and different landforms of glaciated areas. Eight conclusions are offered to further investigations:

(1) Many drumlins appear to be truncated and their material reworked to form moraines;

(2) A least one series of De Geer moraines composed of sorted sediments seems to be associated with an esker system located downglacier;

(3) A sequence, transitional between De Geer moraines and Rogen moraines, was identified in the area of Lac Caopatina (Fig. 6a);

(4) De Geer moraines should be included in glacial landscapes, extending from the streamlining zone to the wastage zone. But, shallow and too deep water will prevent their formation.

(5) Three facies associations are described: a) sorted sediments; b) non-fissile and loose till; c) fissile and compact till. Those three facies associations form a continuum beginning with the series of moraines composed of sorted sediments, and grading laterally into the moraines formed of a fissile and compact till. This transition is identified for the first time;

(6) Deformation structures consist of overturned to recumbent folds, thrust faults, load and drag structures. Those deformation structures are evidence that the glacier was still active when the moraines formed;

(7) The model presented here suggests that the material composing the De Geer moraines of the Chapais and Radisson sectors were deposited in bottom crevasses by an active glacier (Fig. 12). Sorted sediments were deposited as foreset laminations in crevasses in the areas where large amounts of meltwater were concentrated. In the areas where less water was present, till was deposited. The glacier locally remobilized the basal till, thus deforming existing drumlins, to push it toward crevasses located nearby. In the areas where little meltwater was channelized, the glacier constructed the moraines, by deforming till. The origin of De Geer moraines is therefore polygenetic and other processes may be identified in future studies;
(8) De Geer moraines have no relative geochronological value.

\section{ACKNOWLEDGMENTS}

This work was supported by grants from the Natural Sciences and Engineering Research Council of Canada, the Fonds pour la Formation de Chercheurs et l'Aide à la Recherche to the first author, and the Geological Survey of Canada and the Université du Québec à Montréal for the second author. The Société économique de la Baie James provided logistic support in the James Bay area. This paper is part of a Ph.D. thesis presented by the first author, and it benefitted from constructive comments by by Drs. J. Shaw, J.-S. Vincent and P. Pagé. Thanks are also extended to Dr. M. Lamothe for his comments and suggestions, and to Dr. J. Bourne who improved the English text. The authors express their gratitude to Drs. A. Dreimanis, A.D. Miall, M.A. Bouchard, W.B. Thompson, J.-C. Dionne, M. Allard and J. Veillette for their comments, criticism and suggestions. Thanks are extended to Michelle Laithier (drafting), D. Levasseur and F. Hardy who assisted the authors in the field.

\section{REFERENCES}

Alley, R.B., Blankenship, D.D., Bentley, C.R. and Rooney, S.T., 1986. Deformation of till beneath ice stream B, West Antarctica. Nature, 322: 57-59.

-1987. Till beneath ice stream B 3. Till deformation: evidence and implications. Journal of Geophysical Research, 92: 8921-8929.

Andrews, J.T., 1963a. Cross-valley moraines of the Rimrock and Isortoq valleys, Baffin Island, N.W.T. - A descriptive analysis. Geographical Bulletin, 5: 49-77.

-1963b. The cross-valley moraines of north-central Baffin Island: A quantitative analysis. Geographical Bulletin, 5: 82-129.

Andrews, J.T. and Smithson, B.B., 1966. Till fabrics of the cross-valley moraines of north-central Baffin Island, Northwest Territories, Canada. Geological Society of America Bulletin, 77: 271-290.

Avramtchev, L., 1985. Carte géologique du Québec. Ministère de l'Énergie et des Ressources, Québec, Map \#2000.

Aylsworth, J.M. and Shilts, W.W., 1989a. Glacial features around the Keewatin Ice Divide: Districts of Mackenzie and Keewatin. Geological Survey of Canada, Paper 88-24, $21 \mathrm{p}$.

- 1989b. Bedforms of the Keewatin Ice Sheet, Canada. Sedimentary Geology, 62: 407-428.

Barnett, D.M., 1967. Development, landforms and chronology of Generator Lake, Baffin Island, N.W.T. Geographical Bulletin, 9: 160-188.

Barnett, D.M. and Holdsworth, G., 1974. Origin, morphology, and chronology of sublacustrine moraines, Generator Lake, Baffin Island, N.W.T. Canadian Journal of Earth Sciences, 11: 380-408.

Beaudry, L.M., 1988. Morphologie et sédimentologie de moraines de De Geer. Région de Chapais, Québec. M.A. thesis, University of Ottawa, $145 \mathrm{p}$.

Beaudry, L.M. and Prichonnet, G., 1991. Late Glacial De Geer moraines with glaciofluvial sediment in the Chapais area, Québec (Canada). Boreas, 20: 377-394.

Bisson, L., 1987. Géologie des dépôts quaternaires du Canton de Scott, Chibougamau, Québec; avec applications à la prospection minérale. M.Sc. Thesis, Université du Québec à Montréal, 182 p.

Blankenship, D.D., Bentley, C.R., Rooney, S.T. and Alley, R.B., 1986. Seismic measurements reveal a saturated, porous layer beneath an active Antarctic ice stream. Nature, 322: 54-57. 
Boulton, G.S., 1986. Push-moraines and glacier-contact fans in marine and terrestrial environments. Sedimentology, 33: 677-698.

Bouchard, M.A., 1980. Late Quaternary geology of the Témiscamie area, central Québec, Canada. Ph.D. thesis, McGill University, 284 p.

1989. Subglacial landforms and deposits in central and northern Québec, Canada, with emphasis on Rogen moraines. Sedimentary Geology, 62: 293-308.

Bouchard, M.A. and Martineau, G., 1985. Southeastward ice flow in central Quebec and its paleogeographic significance. Canadian Journal of Earth Sciences, 22: 1536-1541.

Brereton, W.E., Sobie, P.A., Sinclair, G.P. and Anderson, M., 1987. Report on a reverse circulation drilling program with 64 logs of holes CW-87-01 to 64 , Chapais West Property. Ministère de l'Énergie et des Ressources, Québec, GM 46449, 381 p.

Brodzikowski, K. and van Loon, A.J., 1987. A systematic classification of glacial and periglacial environments, facies and deposits. Earth Science Reviews, 24: 297-381.

1991. Glacigenic sediments. Development in sedimentology 49 Elsevier, Amsterdam, $674 \mathrm{p}$

Burns, T.E., MacNeil, K.A., Averill, S.A. and Holmes, D., 1986. Report on a reverse circulation overburden drilling program with 227 logs of holes CW-85-1 to CW-85-227, Chapais West Property. Ministère de l'Énergie et des Ressources, Québec, GM 44879, $595 \mathrm{p}$.

De Corta, H., 1984. Dépôts meubles de la région des lacs Rohault et Boisvert. Ministère de l'Énergie et des Ressources, Québec, 2 maps DP-84-52.

1988. Les dépôts quaternaires de la région lac Rohault-lac Boisver (sud de Chibougamau). Aspect de la dispersion glaciaire clastique. M.Sc. thesis, Université du Québec à Montréal, 112 p.

De Geer, G., 1889. Ändmoräner i trakten mellan Spanga och Sundbyberg Geologiska Föreningens i Stockholm Förhandlingar, 11: 395-397.

Dilabio, R.N.W., 1981. Glacial dispersal of rocks and minerals in the Lac Mistassini-Lac Waconichi area, Quebec, with special reference to the Icon dispersal train. Geological Survey of Canada, Bulletin 323, 46 p.

Dreimanis, A., 1979. The problems of waterlain tills, p.167-177. In C Schlüchter, ed., Moraines and varves. Balkema, Rotterdam,

1982. Work Group (I)-Genetic classification of tills and criteria for their differentiation: Progress report on activities 1977-1982, and definitions of glacigenetic terms, p.12-31. In C. Schlüchter, ed., INQUA Commission on genesis and lithology of Quaternary deposits. Report on activities 1977-1982.

1988. Tills: Their genetic terminology and classification, p.17-83. In R.P. Goldthwait and C.L. Matsch, eds., Genetic Classification of Glacigenic Deposits. Balkema, Rotterdam.

Dyke, A.S. and Prest, V.K., 1987. Late Wisconsinan and Holocene history of the Laurentide Ice Sheet. Géographie physique et Quaternaire, 41 237-263.

Elson, J.A., 1968. Wash-board moraines and other minor moraines types p. 1213-1219. In R.W. Fairbridge, ed., Encyclopedia of Geomorphology Reinhold Book Corporation, New York.

Fyfe, G.F., 1990. The effect of water depth on ice-proximal glaciolacustrine sedimentation: Salpausselka I, southern Finland. Boreas, 19: 147-164.

Gipp, M.R., 1992. Ice flow directions deduced from the orientation of lift-off moraines in Emerald Basin, Scotian Shelf. GAC-MAC Abstracts volume, 17: A40.

Gobeil, A. and Racicot, D., 1983. Carte lithostratigraphique de la région de Chibougamau. Ministère de l'Énergie et des Ressources, Québec, MM 83-02, map \#1978.

Goldthwait, R.P., 1974. Rates of formation of glacial features in Glacie Bay, Alaska, p. 163-185. In D.R. Coates, ed., Glacial Geomorphology Publications in Geomorphology, State University of New York Binghamton.
Gray, J.T. and Lauriol, B., 1985. Dynamic of the Late Wisconsin ice sheet in the Ungava Peninsula interpreted from geomorphological evidence. Arctic and Alpine Research, 17: 289-310.

Hardy, L., 1976. Contribution à l'étude géomorphologique de la portion québécoise des basses terres de la baie James, Québec. Ph.D. thesis, McGill University, Montréal, 263 p.

1977. La déglaciation et les épisodes lacustre et marin sur le versant québécois des basses-terres de la baie James. Géographie physique et Quaternaire, 31: 261-273.

-1982. Le Wisconsinien Supérieur à l'est de la baie James, Québec. Naturaliste canadien, 109: 333-351.

Hart, J.K. and Boulton, G.S., 1991. The interrelation of glaciotectonic and glaciodepositional processes within the glacial environment. Quaternary Science Reviews, 10: 335-350.

Herterich, K., 1987. On the flow within the transition zone between ice sheet and ice shelf, p. 185-202. In C.J. van der Veen and J. Oerlemans, eds., Dynamics of the West Antarctic Ice Sheet. D. Reidel Publishing Company.

Hillaire-Marcel, C., Occhietti, S. and Vincent, J.-S., 1981. Sakami moraine, Quebec: A 500-km-long moraine without climatic control. Geology, $9: 210-214$

Holdsworth, G., 1973. Ice deformation and moraine formation at the margin of an ice cap adjacent to a proglacial lake, p. 187-199. In B.D. Fahey and R.D. Thompson, ed., Research in polar and alpine geomorphology. 3rd Guelph Symposium on Geomorphology, Geo Abstracts, Norwich.

Hoppe, G., 1948. Isrecessionen från Norrbotens kustlan i belyning av de glaciala formelementen. English summary: The ice recession from the lower region of Norrbotten as illustrated by the land formations. Geographica, 20: 1-112

1957. Problems of glacial morphology and the Ice Age. Geografiska Annaler, 39: 1-18

1959. Glacial morphology and inland ice recession in northern Sweden. Geografiska Annaler, 41: 193-212.

Ignatius, H., 1956. Late-Wisconsin stratigraphy in north-central Québec and Ontario, Canada. Ph.D. thesis, Yale University, New Haven.

Jezek, K.C. and Bentley, C.R., 1979. Electromagnetic sounding of bottom crevasses on the Ross Ice Shelf, Antarctica. Journal of Glaciology, 24: $321-330$

1983. Field studies of bottom crevasses in the Ross Ice Shelf, Antarctica. Journal of Glaciology, 29: 118-126.

Kamb, B., 1987. Glacier surge mechanism based on linked cavity configuration of the basal water system. Journal of Geophysical Research, 92: 9083-9100.

Krüger, J., 1979. Structures and textures in till indicating subglacial deposition. Boreas, 8: 323-340.

Larsen, E., Longva, O. and Follestad, B.A., 1991. Formation of De Geer moraines and implications for deglaciation dynamics. Journal of Quaternary Science, 6: 263-277.

Loken, O.H. and Leahy, E.J., 1964. Small moraines in southeastern Ontario. Canadian Geographer, 8: 10-21.

Lundqvist, J., 1989. Rogen (ribbed) moraine - identification and possible origin. Sedimentary Geology, 62: 281-292.

Mark, D.M., 1973. Analysis of axial orientation data, including till fabrics. Geological Society of America Bulletin, 84: 1369-1374.

1974. On the interpretation of till fabrics. Geology, 2:101-104.

Martineau, G., 1984. Géologie du Quaternaire, région de Chibougamau. Ministère de l'Énergie et des Ressources, Québec, ET 83-20, 15 p.

Martineau, G., Bouchard, M.A. and Lacroix, P., 1984. Aspects de la géologie du Quaternaire de Chibougamau. Ministère de l'Énergie et des Ressources, Québec, MB 84-13, 24 p. 
Mawdsley, J.B., 1936. The wash-board moraines of the OpawicaChibougamau area, Quebec. Transactions of the Royal Society of Canada, Third Series, 30: 9-12.

Menzies, J., 1989. Subglacial hydraulic conditions and their possible impact upon subglacial bed formation. Sedimentary Geology, 62: 125-150.

Menzies, J. and Rose, J., 1989. Subglacial bedforms - An introduction. Sedimentary Geology, 2: 117-122.

Mickelson, D.M. and Berkson, J.M., 1974. Till ridges presently forming above and below sea level in Wachusset Inlet, Glacier Bay, Alaska. Geografiska Annaler, 56A: 111-119.

Norman, G.W.H., 1938. The last Pleistocene ice-front in Chibougamau District, Quebec. Transactions of the Royal Society of Canada, 32: 6986.

Painchaud, A., Dubois, J.-M.M. and Gwyn, Q.H.J., 1984. Déglaciation et émersion des terres de l'ouest de l'île d'Anticosti, golfe du St-Laurent, Québec. Géographie physique et Quaternaire, 38: 93-111.

Prichonnet, G., 1984. Glaciations d'inlandsis: séquences glaciaires, proglaciaires et non glaciaires du Quaternaire de l'est canadien. Bulletin Centres de Recherche et d'Exploration-Production. Elf-Aquitaine, 8: 105-133.

Prichonnet, G., Martineau, G. and Bisson, L., 1984. Les dépôts quaternaires de la région de Chibougamau, Québec. Géographie physique et Quaternaire, 38: 287-304.

Prichonnet G. and Beaudry, L.M., 1990. Évidences d'un écoulement glaciaire sud, antérieur à l'écoulement sud-ouest du Wisconsinien supérieur, Région de Chapais, Québec. In Current Research, Part C, Geological Survey of Canada, Paper 90-1C: 331-338.

Shaw, G., 1944. Moraines of late Pleistocene ice fronts near James Bay, Quebec. Transactions of the Royal Society of Canada, 38: 79-85.

Shilts, W.W. 1976. Glacial till and mineral exploration, p. 205-224. In R.F. Legget, ed., Glacial till: An interdisciplinary study. Royal Society of Canada, Special Publication 12.

Smith, G.W., 1982. End moraines and the pattern of last retreat from central and south coastal Maine, p. 195-209. in G.J. Larson and B.D. Stone, ed., Late Wisconsinan Glaciation of New England. Kendall-Hunt.

Solheim, A. and Pfirman, S.C., 1985. Sea-floor morphology outside a grounded, surging glacier; Bråsvellbreen, Svalbard. Marine Geology, 65: 127-143.

Sollid, J.L. and Carlsson, A.B., 1984. De Geer moraines and eskers in Pasvik, North Norway. Striae, 20: 55-61.
Strömberg, B., 1965. Mappings and geochronological investigations in some moraine areas of south central Sweden. Geografiska Annaler, 47: 73-82.

Sugden, D.E. and John, B.S., 1976. Glaciers and Landscapes. A Geomorphological Approach. Arnold, London, $376 \mathrm{p}$.

Tremblay, G., 1968. Note sur les crêtes morainiques de Saint-François-deSales. Cahiers de Géographie de Québec, 27: 429-442.

Veillette, J. and Pomares, J.-S., 1991. Older ice flows in the MatagamiChapais area, Québec. In Current Research, Part C, Geological Survey of Canada, Paper 91-1C: 143-148.

Vincent, J.-S., 1977. Le Quaternaire récent de la région du cours inférieur de La Grande Rivière, Québec. Geological Survey of Canada, Étude 76-19, $20 \mathrm{p}$.

_ 1985a. Surficial geology, Radisson, Québec. Geological Survey of Canada, Map \#1591A, scale 1/100 000.

-1985b. Surficial geology, Réservoir La Grande 2, Québec. Geological Survey of Canada, Map \#1590A, scale 1/100 000.

1989. Le Quaternaire du sud-est du Bouclier canadien, p. 266-295, In R.J. Fulton, Le Quaternaire du Canada et du Groenland. Geological Survey of Canada, Geology of Canada, vol. 1. (The Geology of North America, vol.K-1, Geological Society of America).

Vincent, J.-S. and Hardy, L., 1977. L'évolution et l'extension des lacs glaciaires Barlow et Ojibway en territoire québécois. Géographie physique et Quaternaire, 31: 357-372.

1979. The evolution of glacial lakes Barlow and Ojibway, Quebec and Ontario. Geological Survey of Canada, Bulletin 316, 18 p.

Vincent, J.-S., Veillette, J.J., Allard, M., Richard, P.J.H., Hardy, L. and Hillaire-Marcel, C., 1987. Dernier cycle glaciaire et retrait des glaces de la vallée supérieure de l'Outaouais jusqu'au sud-est de la baie d'Hudson. INQUA 87, excursion C-10, $87 p$.

Vornberger, P.L. and Whillans, I.M., 1990. Crevasse deformation and examples from Ice Stream B, Antarctica. Journal of Glaciology, 36: 310 .

Zilliacus, H., 1987a. The De Geer moraines in Finland, p. 711-724. In V Gardiner, ed., International Geomorphology 1986 Part II. John Wiley.

1987b. De Geer moraines in Finland and the annual moraine problem. Fennia, 165: 145-239.

1989. Genesis of De Geer moraines in Finland. Sedimentary Geology, 62: 309-317. 